\title{
Contentious Business: Merchants and the Creation of a Westernized Judiciary in Hawai'i
}

\author{
Wendie Ellen Schneider
}

There it towered where each of its antecedents

had stood in a cloud-hidden unremembered past

-W.S. Merwin, The Mountain ${ }^{1}$

On October 8, 1841, Henry Skinner made history in Honolulu. Skinner, a British merchant, sued John Dominis, an American sea captain, for breach of contract. Dominis had taken $\$ 10,000$ of Skinner's money to invest in goods in China, and the two disagreed about the disposition of the cargo that Dominis had acquired. The content of their dispute was hardly noteworthy, but the forum in which it took place was: Skinner broke with local tradition by taking a mercantile dispute to the Kingdom of Hawai'i's courts $^{2}$ for resolution. Previously, such disputes had been handled by the foreign merchants themselves in arbitration proceedings. Skinner's enthusiasm for the monarchical courts was short-lived, however. After a jury was impaneled on October 13, Skinner "objected to all the jury," primarily because of the predominance of Americans, and, in the words of an observer," [p]rotested against The Court!" 3 Skinner's case was subsequently dismissed by the government after he refused to attend a retrial. Skinner then attempted to demand damages from the King himself, Kamehameha III. ${ }^{4}$

Skinner was no lawyer, and he ultimately gained nothing from his illconsidered innovation. Nonetheless, his case is a turning point in Hawaiian (1998).

1. W.S. MERWIN, THE FOLDING ClIFFS: A NARRATIVE OF 19TH-CENTURY HAWAII 47,48

2. Hawai' $i$ remained an independent kingdom until the foreign-led revolution of 1893 and annexation by the United States in 1898 .

3. 5 Stephen Reynolds, Journal 476 (entry of Oct. 13, 1841) (original on file with the Peabody-Essex Museum, Salem, Mass., typescript available at the Hawaiian Mission Children's Society Library, Honolulu, Haw.). The first portion of his journals have been published. 1 STEPHEN REYNOLDS, JOURNAL OF STEPHEN REYNOLDS (Pauline King ed., 1989) covers the years 1823-1829. I am indebted to Lani Ma'a Lapilio, Susan Shaner, Esther Kiki Mookini, Matt Mattice and Mamo Koki of the Judiciary History Center, Honolulu, for their generous assistance throughout this project.

4. See 5 Reynolds, supra note 3 , at 480 (entry of Oct. 22,1841 ). 
legal history. ${ }^{5}$ This Note seeks to demonstrate both that Skinner's case signaled a crucial shift in the disputing habits of foreigners in Hawai' $i$ and that recognizing this shift would correct the conventional understanding of Hawai 'i's judicial westernization held by courts and scholars. In particular, they have used a "recuperative" model of historical exposition as a crucial technique in the legal determination of traditional Hawaiian rights. This model seeks to recover promises made and broken by the legal system. ${ }^{6}$ By focusing on the creation of a westernized system of land ownership, the "recuperative" model seeks to reveal a more generous understanding of the early laws establishing the rights of Hawaiian cultivators. ${ }^{7}$ While this model does much to uncover previously neglected alternatives, it relies upon a fundamentally incomplete narrative of the founding of Hawai'i's courts. This Note suggests that, by ignoring the role of the merchants in the creation of a westernized judiciary, modern courts overestimate the relevance of judicial precedents of the Kingdom and underestimate the extent to which the first courts were foreign impositions on a plural legal system.

Before turning to the conflict among different legal systems, it is useful to recall Hawai'i's political situation. The shift in disputing patterns and the creation of a westernized legal system were also integral parts of a larger process of growing foreign control over Hawai' $i$. In turning to the Kingdom's courts, Skinner was the first in a long line of foreigners to demand the application of international (largely American) commercial law. As a result, during the 1840 s a western-style legal system was adopted and largely staffed by whites; ${ }^{8}$ the rest of the government followed suit rapidly thereafter. ${ }^{9}$ Foreign domination of the Hawaiian government long preceded actual annexation by the United States in $1898 .^{10}$ Thus, the story of the collapse of merchant arbitration has a role in the narrative of imperial expansion in Hawai' $i$. While the political consequences of the merchants' shift to Kingdom courts are dramatic, their motives for making this transition remain unexplored. Before the $1840 \mathrm{~s}$, foreigners sought to

5. Skinner's case is briefly mentioned in two standard histories. See HAROLD WHITMAN BRADlEY, THE AMERICAN FroNTIER IN HAWAII: THE PIONEERS, 1789-1843, at 399-400 (1942); RALPH S. KUYKENDALL, THE HAWAIIAN KINGDOM, 1778-1854, at 209 (1938).

6. See infra text accompanying notes 31-33.

7. See infra Section I.B.

8. See MARSHALl SAHLINS, ANAHULU: THE ANTHROPOLOGY OF HISTORY IN THE KINGDOM OF HAWAII 3 (1992).

9. See Gavan Daws, Shoal of Time: A History of the Hawailan ISLANDS 108 (1968) ("By the end of 1844 there were fourteen white men working for the government; by 1851, fortyeight.").

10. This Note does not deal with the events surrounding the annexation. For the fullest scholarly account of those events, see WILLIAM ADAM RUSS, JR., THE HAWAIIAN REPUBLIC (1894-98) (1992); and WILliAM ADAM RuSS, JR., THE HAWAIIAN REVOLUTION (1893-94) (1959). 
resolve disputes among themselves through arbitration. They were unwilling to take the risk of turning to courts under the authority of Hawaiians, whom they distrusted. ${ }^{11}$ While there are a number of very good accounts of Hawaiian history covering this period, ${ }^{12}$ none fully explains how merchant arbitration broke down so dramatically. Land hungerforeigners' desire to hold their land in fee simple, without fear of eviction by the King-is often thought to be the driving motivation. Yet, desire for land does little to account for the growth of commercial litigation. ${ }^{13}$

To explain why Skinner and other foreigners turned to Hawaiian courts, this Note emphasizes two developments that have been neglected: (1) the role of foreign merchants in provoking the westernization of Hawai'i's judiciary ${ }^{14}$ and (2) the interaction of the multiple legal systems active in Hawai $i$ at the time. ${ }^{15}$ What occurred in the 1840 s was a breakdown of the norms governing the balance between different legal systems-a breakdown in which merchant interests predominated. But this breakdown did not simply shift merchant litigation from arbitration to Hawaiian courts.

11. See, e.g., THE POLYNESIAN (Honolulu), May 8, 1841, at 191 ("The gross abuses growing out of the system of paying the judges from fines collected from offending parties has engaged [the government's serious attention]."); Letter from Richard Charlton, British Consul to Hawai 'i, to Viscount Palmerston (Nov. 23, 1836), in CORRESPONDENCE RELATIVE TO THE SANDWICH ISLANDS, 1824-1843, at 44, 45 (London, privately printed for use of the Cabinet, 1844) [hereinafter CORRESPONDENCE] ("The laws are few, and those badly administered; indeed, justice is not known among these people.").

12. See generally BRADLEY, supra note 5; DAWS, supra note 9; KUYKENDALL, supra note 5; SAHLINS, supra note 8 (histories of Hawai' $i$ in the 19th century). For an economic perspective, See THEODORE MORGAN, HAWAII: A CENTURY OF ECONOMIC CHANGE, 1778-1876 (1948).

13. See infra Section I.C.

14. Merchants have been largely ignored in Hawaiian legal history. One influential scholar, for example, identifies three groups as active in imposing a western judicial system in Hawai' $i$ : women ali' $i$ (aristocrats), missionaries, and American lawyers hired by the government to stave off colonization. See Jane L. Silverman, Imposition of a Western Judicial System in the Hawaiian Monarchy, 16 HAWAIIAN J. HIST. 48, 48 (1982).

15. It is important to recognize that Hawai'i in the 1830 s possessed a plural legal system. Legal pluralism is defined as "a situation in which two or more legal systems coexist in the same social field." Sally Engle Merry, Legal Pluralism, 22 L. \& SOC'Y REV. 869, 870 (1988). In this Note, however, I distinguish between the legal pluralism of the 1830 s, in which no single system claimed a dominant position, and the system as of 1858 , in which the newly-westernized legal system asserted its authority over all other institutions. While the latter system is still a plural one under Merry's broad definition, I restrict the description to the earlier system to emphasize the autonomy of the different, coexisting institutions. Merry traces the idea of legal pluralism back to Leopold Pospisil's pioneering formulation: "Any human society ... does not possess a single consistent legal system, but as many such systems as there are functioning subgroups." LEOPOLD POSPISIL, ANTHROPOLOGY OF LAW 98 (1974). Sally Falk Moore's idea of "semi-autonomous social fields," each of which "[has its] own customs and rules and the means of coercing or inducing compliance" also contributes to this definition of legal pluralism. SALLY FALK MOORE, LAW AS PROCESS 56-57 (1978). Moore advocates studying each field as a site of law. See also Marc Galanter, Justice in Many Rooms: Courts, Private Ordering, and Indigenous Law, $19 \mathrm{~J}$. LEGAL PLURALISM 1 (1981) (describing research into the many systems of normative ordering outside of the formal court system); John Griffiths, What Is Legal Pluralism?, 24 J. LEGAL PLURALISM 1, 38 (1986) (agreeing with Moore's formulation). For discussion of the systems operating in Hawai $\mathrm{i}$, see infra Part II. 
It also laid the foundation for an unprecedented unification of legal activity in Hawai' $i$ under a newly-created and exclusively western court system.

This Note begins, in Part I, with a summary of modern courts' "recuperative" interpretation of the history of judicial westernization in the 1840s and the problems with reliance on land hunger as an explanation for westernization. Part II examines in greater detail the different systems of justice that co-existed during the 1830s and describes the often-overlooked world of merchant justice. Part III discusses the breakdown of this system in the early 1840s. The results of the change-challenges to Hawaiian sovereignty, the growing Caucasian role in Hawaiian government in the 1840 s, and the culmination of a process of judicial unification-are briefly outlined in Part IV. Finally, Part V suggests some of the implications of this reevaluation of foreign involvement in the establishment of a western-style judiciary in Hawai' $i$.

\section{REVISITING THE $1840 \mathrm{~s}^{16}$}

The crucial stages of judicial westernization in Hawai ' $i$ occurred in the 1840s. Modern courts have, therefore, revisited the history of this decade to discover the nature of traditional Hawaiian rights. In large part, this history has drawn on a "recuperative" model of legal change that seeks to uncover alternative trajectories that might have preserved a greater degree of Hawaiian autonomy. This Part briefly introduces the historical background to Hawai' $i$ in the 1840 s and then describes the courts' interpretation of this important decade. It concludes by questioning the modern courts' reliance on western land hunger as the sole motive force behind westernization and argues that one of the limitations of the "recuperative" model is its neglect of legal pluralism.

\section{A. Historical Background}

Even as it was poised to embark on further changes, Hawaiian society in the $1830 \mathrm{~s}$ and $1840 \mathrm{~s}$ had just undergone several dramatic transformations. Since the time of Captain James Cook's visit to the islands in 1778, the archipelago had been unified into a single Kingdom in 1810 by Kamehameha I, an ali $i$ (aristocrat) from the island of Hawai ' $i$. For reasons

16. It should be noted at the outset that this Note does not presume to represent the Hawaiian side of the story. The Note's main focus is a reexamination of western involvement. For accounts assessing the Hawaiian reaction to these events, see Mari J. Matsuda, Law and Culture in the District Court of Honolulu, 1844-1845: A Case Study of the Rise of Legal Consciousness, 32 AM. J. LEGAL HIST. 16 (1988); and Caroline Ralston, Hawaii 1778-1854: Some Aspects of Maka'ainana Response to Rapid Cultural Change, 29 J. PAC. HIST. 21 (1984). 
still debated by scholars, ${ }^{17}$ Kamehameha I's successors chose to make a second significant change after his death in 1819 with the abolition of the traditional kapu (taboo) system, which had ascribed divine authority to kings and imposed harsh sanctions for insubordination. The practical consequence of the abolition was to encourage a search for alternate sources of legitimacy. Some ali $i$ seized upon both Christianity, when it arrived in the islands, and the laws advocated by the missionaries, as new sources of power and authority.

Meanwhile, on the other side of the globe, American Protestants were turning their attention to Hawai $i$. The arrival of a Hawaiian youth named Opukahai'a in New Haven in 1809 fueled support for a Hawaiian mission. ${ }^{18}$ The American Board of Commissioners for Foreign Missions (ABCFM), an umbrella group composed of northeastern Protestants, particularly seminarians from Yale, Dartmouth, and Princeton, sent its first group of missionaries to Hawai' $i$ in $1820 .^{19}$ They met with rapid success. $\mathrm{Ka}^{\text {'ahumanu, }}{ }^{20}$ the regent and Kamehameha I's widow, supported the missionaries and employed them in her service. ${ }^{21}$ After Kamehameha II's death in 1824 , ali $i$ aligned with Ka'ahumanu were baptised, signaling the political ascendancy of the missionaries. ${ }^{22}$ Throughout the 1830 s, members of the mission took on important advisory roles in the Hawaiian government. $^{23}$

In the 1840s, under pressure from foreign governments and with the guidance of his missionary advisors, Kamehameha III (1824-1854)

17. The kapu system was abandoned by high-ranking members of the ali $i$ before the arrival of western missionaries. There are a number of competing theories to explain this shift. A traditional view was that repeated violations of kapu by foreigners eroded the Hawaiian belief in the divinity of the kapu commands. See, e.g., W.F. Frear, Hawaiian Statute Law, in THIRTEENTH ANNUAL REPORT OF THE HAWAIIAN HISTORICAL SOCIETY 15, 19-20 (1906) ("[F]rom contact with the visitors, the Hawaiians lost respect for their idolatrous religion and oppressive taboo system."). Another school of thought points to the role of women ali ' $i$ in initiating the abolition. See, e.g., JOCELYN LINNEKIN, SACRED QUEENS AND WOMEN OF CONSEQUENCE 70 (1990) ("[T]he most salient aspect of the kapu abolition is that it was instigated by women."). A more recent interpretation argues that these factors must be understood against the backdrop of depopulation and the resulting anxiety on the part of leaders to find a new basis for rulership. See LILIKALA KAME'ELEIHIWA, NATIVE LAND AND FOREIGN DESIRES 67-93 (1992).

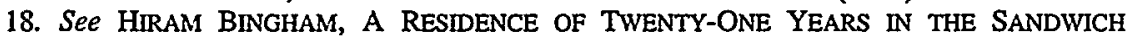
IsLANDS 69 (Hartford, Hezekiah Huntington 1848); Nancy Cassella \& Nancy Martin, The Hawaiian Connection, J. NEW HAVEN COLONY HIST. SOC'Y, Winter 1978, at 15, 17. 18.

19. For a detailed autobiography of one of the early missionaries, see BINGHAM, supra note

20. For a modern biography of Ka'ahumanu, see JANE L. SILVERMAN, KAAHUMANU: MOLDER OF CHANGE (1987).

21. See LaURA Fish Judd, Honolulu: SKETChes of LIFE IN THE HaWAIIAN ISLANDS FROM 1828 TO 1861, at 11 (Dale L. Morgan ed., The Lakeside Press 1966) (1880).

22. See BRADLEY, supra note 5, at 145; 1 REYNOLDS, supra note 3, at 114 (entry of Dec. 4, 1824); SAHLINS, supra note 8, at 67-73.

23. Three of the most prominent advisers were Hiram Bingham, Gerrit P. Judd, and William Richards. For modern (but generally adulatory) biographies, see GERRIT P. JUDD IV, DR. JUDD: HAWAII'S FRIEND (1960); and SAMUEL WILLISTON, WILLIAM RICHARDS (1938). 
instituted a sweeping legal transformation in Hawai' $i$. His reign encompassed a number of radical changes in Hawaiian law, including the introduction of constitutional government and fee simple land tenure. One later nineteenth-century judge described the years 1839 to 1852 as a "peaceful but complete revolution in the entire polity of the Kingdom ...." ${ }^{24}$ It is this period that has drawn the most attention from modern courts.

\section{B. Judicial Histories}

Hawaiian courts have increasingly turned to history in their construction of a judicial basis for Native Hawaiian rights. The story of the westernization of the Kingdom courts, in particular, has assumed prominence recently, as lawyers and activists search for legal solutions to the problems faced by Native Hawaiians. ${ }^{25}$ The Hawaiian state courts have encouraged such efforts through their recognition of the continuing vitality of Native Hawaiian rights based on precedents and statute law of the Kingdom of Hawai ${ }^{1}{ }^{26}{ }^{26}$ Land rights, ${ }^{27}$ water rights, ${ }^{28}$ fishing and water access, ${ }^{29}$ and gathering rights ${ }^{30}$ all have been examined with reference to the legal history of the Kingdom.

24. In re Estate of His Majesty Kamehameha IV, 2 Haw. 715, 720 (1864).

25. At the same time, Hawaiian nationalists have used legal controversy to advance their cause: staging mock trials, for example, or refusing to recognize American courts. For examples of such refusals, see Sally Engle Merry, Law, Culture, and Cultural Appropriation, 10 YALE J.L. \& HUMAN. 575, 586 (1998); and William H. Rodgers, Jr., The Sense of Justice and the Justice of Sense: Native Hawaiian Sovereignty and the Second "Trial of the Century," 71 WASH. L. REv. 379, 388-90 (1996). For an overview of the Hawaiian sovereignty movement, see Davianna McGregor, $\mathrm{Ho}^{\prime} i \mathrm{Ho}^{\prime} \mathrm{i}$ Ea Hawaii: Restoring Hawaiian Sovereignty, in INSTTTUTE OF PACIFIC STUDIES, NEW POLITICS IN THE SOUTH PACIFIC 31, 31-54 (1994).

26. See Public Access Shoreline Haw. ("PASH") v. Hawai 'i County Planning Comm'n, 903 P.2d 1246 (Haw. 1995); Pele Defense Fund v. Paty, 837 P.2d 1247 (Haw. 1992); Kalipi v. Hawaiian Trust Co., 656 P.2d 745 (Haw. 1982). See generally NATIVE HawAIIAN RIGHTS HANDBOOK (Melody Kapilialoha MacKenzie ed., 1991) (outlining Native Hawaiian rights); Davianna Pomaika 'i McGregor, An Introduction to the Hoa'aina and Their Rights, 30 HAWAIIAN J. HIST. 1, 10-13 (1996) (providing background to Hawaiian rights).

27. See Pai 'Ohana v. United States, 875 F. Supp. 680 (D. Haw. 1995); Maivân Clech Lâm, The Kuleana Act Revisited: The Survival of Traditional Hawaiian Commoner Rights in Land, 64 WASH. L. REv. 233 (1989); Neil M. Levy, Native Hawaiian Land Rights, 63 CAL. L. Rev. 848 (1975); Bradley Hideo Keikiokalani Cooper, Comment, A Trust Divided Cannot Stand-An Analysis of Native Hawaiian Land Rights, 67 TEMP. L. REV. 699 (1994).

28. See Robinson v. Ariyoshi, 753 F.2d 1468 (9th Cir. 1985), vacated, 477 U.S. 902 (1986); Reppun v. Board of Water Supply, 656 P.2d 57 (Haw. 1982); McBryde Sugar Co. v. Robinson, 504 P.2d 1330 (Haw. 1973); Elizabeth Ann Ho'oipo Kala'ena'auao Pa Martin et al., Cultures in Conflict in Hawai ' $i$ : The Law and Politics of Native Hawaiian Water Rights, 18 U. HAW. L. REV. 71 (1996).

29. See Alan Murakami, Konohiki Fishing Rights and Marine Resources, in NATTE HAWAIIAN RIGHTS HANDBOOK, supra note 26, at 173-95.

30. See Daniel G. Mueller, The Reassertion of Native Hawaitan Gathering Rights Within the Context of Hawai' $i$ 's Western System of Land Tenure, 17 U. HAW. L. REV. 165 (1995); Pam Bunn \& Wayne Costa, Note, Public Access Shoreline Hawaii v. Hawai 'i County Planning Commission: 
These decisions have used what might be called a "recuperative" model of history, building on Robert Gordon's description of one of the aims of critical historicism as being to "recover suppressed alternatives." 31 One version of this model depicts law as broken promises. ${ }^{32}$ Where the law guarantees certain rights to all, for example, exigencies of power dictate that only some can enjoy those rights. To locate a foundation for modern Native Hawaiian rights, critical legal scholars have seized upon the themes of broken promises and suppressed alternatives in their excavation of the Hawaiian past. ${ }^{33}$ The initial phases of westernized land tenure, in particular, have been shown to contain a rich history of promises made to Hawaiian cultivators that would have guaranteed the continuance of traditional practices, but were later reneged upon by westernized courts.

To recover this heritage of promises, modern courts have had to find a way around Kingdom precedents that impose western land tenure with no consideration for Hawaiian needs. The most important decision of this type is Oni v. Meek, ${ }^{34}$ a case decided in 1858. In Oni, the Hawaiian Supreme Court examined the question of customary rights (in this case, the right of pasturage) for the first time and decisively rejected their legality. The court declared: " $[\mathrm{I}] \mathrm{t}$ is obvious to us that the custom contended for is so unreasonable, so uncertain, and so repugnant to the spirit of the present laws, that it ought not to be sustained by judicial authority." ${ }^{35}$ Oni thereby laid down the fundamental law on the (non)recognition of Hawaiian custom that persisted until the $1980 \mathrm{~s}^{36}$

The modern Hawaiian courts have employed Kingdom statutory law in their recovery of alternatives to the western land-tenure system mandated by Oni. In the landmark 1982 case Kalipi v. Hawaiian Trust Co. ${ }^{37}$ the Hawaiian Supreme Court asserted that customary Hawaiian gathering rights claimed by the tenants of an ahupua' $a$ (a traditional division of land) would

The Affirmative Duty To Consider the Effect of Development on Native Hawaiian Gathering Rights, 16 U. HAW. L. REv. 303 (1994).

31. Robert W. Gordon, The Past as Authority and as Social Critic: Stabilizing and Destabilizing Functions of History in Legal Argument, in THE HISTORIC TURN IN THE HUMAN SCIENCES 339, 364 (Terrence J. McDonald ed., 1996) [hereinafter Gordon, Past as Authority]. For other discussions of this idea, see William W. Fisher III, Texts and Contexts: The Application to American Legal History of the Methodologies of Intellectual History, 49 STAN. L. REV. 1065, 1097-101 (1997); Robert W. Gordon \& William Nelson, An Exchange on Critical Legal Studies Between Robert W. Gordon and William Nelson, 6 LAW \& HIST. REV. 139, 178 (1988); and Robert W. Gordon, Foreword: The Arrival of Critical Historicism, 49 STAN. L. REV. 1023, 1024 (1997).

32. See Gordon, Past as Authority, supra note 31, at 351.

33. See, e.g., Lâm, supra note 27.

34. 2 Haw. 87 (1858).

35. Id. at 90 .

36. See NATIVE HAWAIIAN RIGHTS HANDBOOK, supra note 26, at 214-15; Lâm, supra note 27 , at $270-72$.

37. 656 P.2d 745 (Haw. 1982). 
be upheld. The court pointed to Section 7-1 of the Hawaii Revised Statutes, which was first passed in 1851 as part of the creation of private property in land and which has remained part of Hawaiian law without significant modification since that date. Section 7-1 preserves certain rights for tenants, such as gathering rights, water use, and access. ${ }^{38}$ In Kalipi, the court found that the gathering rights asserted by the claimants were among those enumerated rights.

Despite the apparent contradiction, in Kalipi the modern court strove mightily to avoid overturning the relevant Kingdom precedents, particularly Oni. ${ }^{39}$ Kalipi avoided conflict with Oni, which appeared to close off the appeal to custom, by distinguishing the custom at issue in Kalipi (gathering rights) from that rejected by the court in Oni (horse pasturage). ${ }^{40}$ Understandably, the modern court tried to recover forgotten promises within the precedential system rather than challenging the legitimacy of earlier decisions.

Working within the framework set up by Kalipi, the modern courts, in exploring these issues, have engaged in extensive historical exegeses. In the recent case of Public Access Shoreline Hawaii v. Hawai' $i$ County Planning Commission, ${ }^{41}$ which placed an obligation on state agencies to protect customary and traditional rights, the court devoted much of its opinion to a discussion of recent cases analyzed against a backdrop of early Hawaiian history. ${ }^{42}$ It ultimately concluded that "[an] examination of the relevant legal developments in Hawaiian history leads us to the conclusion that the western concept of exclusivity is not universally applicable in Hawai ' $\mathrm{i} .{ }^{243}$ Perhaps taking their cue from these victories for Hawaiian rights, decisions less favorable to Hawaiian rights activists have also relied on history. Pai 'Ohana v. United States, ${ }^{44}$ another case decided in 1995, relied on an extensive review of the origin and scope of Native Hawaiian land-rights, ${ }^{45}$ but ultimately dismissed the suit brought on behalf of a native Hawaiian group claiming title to a public park. ${ }^{46}$

Reppun v. Board of Water Supply, ${ }^{47}$ an earlier case, similarly reviewed the history of Hawaiian water rights. ${ }^{48}$ In Reppun, the court held for taro growers hurt by the diversion of their water supply and concluded that a

\footnotetext{
39. 2 Haw. 87 (1858).

40. See Kalipi, 656 P.2d at $750-52$.

41. 903 P.2d 1246 (Haw. 1995).

42. See id. at 1258-69.

43. Id. at 1268 .

44. 875 F. Supp. 680 (D. Haw. 1995).

45. See id. at 685-88.

46. See id. at 701 .

47. 656 P.2d 57 (Haw. 1982).

48. See id. at 64-69.
}

38. See id. at 748 (quoting HAW. REV. STAT. $\$ 7-1$ (1976)). 
historical examination of riparian rights in Hawai i $i$ revealed a prohibition on the severance of riparian rights from the land. ${ }^{49}$ This embrace of "recuperative" history contrasts with earlier judicial complaints regarding enforced historicism. In the 1973 case that provided the foundation for the decision in Reppun, the court lamented: "It does seem a bit quaint in this age to be determining water rights on the basis of what land happened to be in taro cultivation in 1848. Surely any other system must be more sensible." 50

Through this "recuperative" historicism, Hawaiian courts have reached a rough consensus on the history of the reign of Kamehameha III, albeit one with differing emphases from opinion to opinion. ${ }^{51}$ They see the establishment of a western-style legal system as a response to land hunger ${ }^{52}$ on the part of westerners. The court has described Kamehameha III as " [r]esponding to pressure exerted by foreign residents who sought fee title to land" 53 and the 1840 Constitution as "an attempt to deal with chiefs and foreigners who sought to vest land rights without the required consent of the King." 54 According to this view, land hunger necessitated the creation of a westernized judiciary, because the security of fee-simple title depended on separating land ownership from royal acquiescence. ${ }^{55}$ Another variant of this story stresses the monarchy's resistance to foreign intrusion ${ }^{56}$ and efforts to protect commoners' rights. ${ }^{57}$

The courts' vision of Hawaiian legal history is radically incomplete, however. The creation of a judiciary under Kamehameha III was not just

49. See id. at 72 .

50. McBryde Sugar Co. v. Robinson, 504 P.2d 1330, 1340 n.15 (Haw. 1973).

51. One shift in emphasis relates to the role attributed to the monarchy. A less popular version attributes little agency to Kamehameha III. Instead, his missionary advisors are identified as primarily responsible for the change. The court stresses the importance of the missionaries' role in its McBryde decision:

We are aware that the missionaries, many of whom came from Massachusetts, not only brought the Christian religion to the Hawaiian people, but also brought with them the English common law as recognized in Massachusetts. Also, history shows that missionaries had tremendous influence among the leaders of the Hawaiian Kingdom. Id. at 1342. The McBryde court even surveyed early 19th-century decisions in Massachusetts to determine what sort of water rights regime existed in Hawai' i. See id. at 1342-43. Despite the focus on the role played by missionaries, however, the McBryde decision still remains a story about land ownership.

52. There are several good histories of land tenure in Hawai i. See, e.g., JON J. CHINEN, THE GREAT MAHELE: HAWAII'S LAND DIVISION OF 1848 (1958); KAME'ELEIHIWA, supra note 17; SAHLINS, supra note 8. But see Sumner J. La Croix \& James Roumasset, The Evolution of Private Property in Nineteenth-Century Hawaii, 50 J. ECON. HIST. 829 (1990) (challenging the traditional histories and suggesting that the transition to private property in land was driven, in part, by considerations of public finance).

53. State v. Zimring, 566 P.2d 725, 729 (Haw. 1977).

54. Public Access Shoreline Haw. v. Hawai'i County Planning Comm'n, 903 P.2d 1246, 1264 (Haw. 1995).

55. See KAME'ELEIHIWA, supra note 17, at 170-71.

56. See Public Access, 903 P.2d, at 1265.

57. See Reppun v. Board of Water Supply, 656 P.2d 57, 66 (Haw. 1982). 
about settling land claims. Nor were the courts founded by a coalition comprised solely of missionaries and monarchs. The types of disputes that originally came to the Hawaiian courts, like Skinner's claim, cannot be encompassed within a model viewing land claims as the driving force behind the westernization of Hawai'i's judiciary. Merchants and commercial disputes played a central role in the shift to westernized courts-a shift that must be understood in the context of disparate groups' interests and pre-existing plural legal systems.

\section{What's Wrong with the "Land Hunger" Explanation}

Land hunger, at first blush, is an appealingly rational explanation in that it conforms to common knowledge that later western economic involvement in Hawai' $i$ centered on agriculture, particularly sugar plantations. Unfortunately, this perceived conformity tempts us to read history backward and to derive motivations from subsequent events. The dramatic growth in foreign agricultural interests in Hawai' $i$ followed the establishment of the judiciary. ${ }^{58}$ While experimentation with sugar cultivation began in the 1830s, foreign economic interest in Hawai' $i$ during the 1840s remained focused on commerce, particularly the trade associated with whaling. ${ }^{59}$

Certainly, land claims did figure among the original disputes that led to the creation of a westernized judiciary, including most prominently the British Consul's notorious claim to ownership of most of Honolulu's waterfront on the basis of almost certainly forged documentation. ${ }^{60}$ Such claims, however, formed but a small subset of the larger range of commercial disputes that came into the Kingdom courts. ${ }^{61}$ It is only because the entire process has been interpreted as land hunger that previous scholarship has emphasized these cases to the exclusion of the other, more numerous commercial cases.

The secondary status of property issues in the founding of the western judiciary is reflected in the court's slowness in reaching the question of land rights. The landmark case establishing the primacy of fee-simple land

58. Sugar growing was, during the 1830 s and 1840 s, in its experimental phase. It was not until after 1850 that it assumed its dominant position in the Hawaiian economy. See KUYKENDALL, supra note 5, at 171-82, 314-16; Carol A. MacLennan, Foundations of Sugar's Power: Early Maui Plantations, 1840-1860, 29 HAWAIAN J. HIST. 33 (1995). Thereafter, as W.S. Merwin puts it, "the ranches of the foreigners spread like a change of climate." MERWIN, supra note 1 , at 85 .

59. See Ralph S. Kuykendall, American Interests and American Influence in Hawaii in 1S42, in THIRTY-NINTH ANNUAL REPORT OF THE HAWAIIAN HISTORICAL SOCIETY 48, 49 (1930).

60. See KUYKENDALL, supra note 5, at 208-09, 215, 223-25, 245-46.

61. See infra Part III. 
ownership, Oni $v$. Meek, ${ }^{62}$ came more than a decade after the establishment of the judiciary, and almost two decades after the initial turn to the Hawaiian courts by foreigners.

A second problem with the idea of land hunger as the cause of judicial westernization is that it conflates two separate processes: the creation of a westernized land-tenure system and the creation of a westernized judiciary. The land-tenure system was created by a parallel, but independent, process of legislation. The Legislature first established a Board of Commissioners To Quiet Land Titles (known as the Land Commission) in 1845, and then passed regulations for their work from 1848 to $1855 .^{63}$ Although the personnel executing these policies overlapped, even participants saw the two systems as fundamentally separate. William Little Lee, for example, the first Supreme Court Justice of Hawai $i$, who also sat on the Land Commission, saw the two processes as separate and described them so in a letter to Simon Greenleaf, his former teacher at Harvard, in 1847: "My judicial duties are arduous, but they are small compared with my labors as President of the Board of Commissioners to quiet Land Titles." ${ }^{64}$

\section{Legal Pluralism and the Limits of "Recuperative" History}

While the "recuperative" history of land tenure has done much to establish Native Hawaiian land rights, it also serves, ironically, to reinforce the domination of the western courts that it seeks to criticize. Implicit in the "recuperative" model, particularly when applied by the modern courts, is the idea of a unitary legal system. Legal pluralism does not fit into a model that seeks to make the dominant legal system make good on its own broken promises. The "recuperative" model looks inward for solutions; legal pluralism reminds us that the establishment of a unitary legal system was an act of usurpation.

This difference can be seen in the role of "bargaining" in the establishments of private land ownership and a western legal system respectively. Creation of the land-tenure system involved a bargain, an attempt by the King and the Legislature to preserve traditional Hawaiian gathering customs and the maka'ainana's (commoners') way of life. ${ }^{65}$ Evidence of these negotiations, such as the Bill of Rights of 1839, the Constitution of 1840 or the principles laid out by the Land Commission,

62. 2 Haw. 87 (1858).

63. See CHINEN, supra note 52, at 8-14; Richard A. Greer, Notes on Early Land Titles and Tenure in Hawai ' $i$, 30 HawaIIAN J. HIST., 29, 40-47 (1996).

64. Letter from William Little Lee to Simon Greenleaf (Nov. 2, 1847) (on file with the Bancroft Library, Univ. of Cal., Berkeley).

65. See KAME`ELEIHIWA, supra note 17, at 201-25; SAHLINS, supra note 8, at 136; Lâm, supra note 27, at 253-60. 
can be returned to by "recuperative" historicists seeking to enforce the bargain in a way that honors the intentions of the monarchy and the rights of cultivators. ${ }^{66}$

By contrast, the creation of the westernized judiciary involved no such bargain; no aspect of traditional Hawaiian dispute resolution or concept of justice was preserved under it. The establishment of the new judiciary was apparently intended to appease foreign residents who demanded a new forum for disputes in which they could apply their own laws, not to serve as the sole legal system for all of Hawai' ${ }^{6} .{ }^{67}$ But this was left unsaid.

Later, this oversight came back to haunt the Hawaiians. Because the westernized judiciary existed, it became the forum in which land claim disputes were ultimately decided. In Oni, the two separate systemsnamely, the westernized judiciary and the land-tenure system-converged, much to the detriment of Native Hawaiians. At the time, no one questioned the legitimacy of evaluating the validity of Hawaiian rights through a judiciary established to meet foreign needs. This usurpation still passes unremarked by the "recuperative" critics, because they seek their lost promises within the records of the westernized judiciary, overlooking the plural system that that judiciary replaced. ${ }^{68}$

One goal of this Note is to suggest that Oni should be read as marking the death of a plural legal system - the triumph of a foreign-oriented court system that had moved from an auxiliary status to a position of dominance over all other legal systems in the Kingdom-as well as the culmination of fee-simple land tenure that it is normally taken to symbolize. The mountain, to borrow W.S. Merwin's image, could then tower over its "cloud-hidden unremembered" antecedents. This transition becomes visible when we view the westernized judiciary as a concession to foreign demands for a new forum.

\section{HONOLULU IN THE 1840S: FOREIGNERS AND FORA}

To understand why the Hawaiian monarchy would try to cordon off foreign disputes through the creation of a westernized judiciary, some background information is necessary. This Part will explore first, who the contentious foreigners were, and second, how they previously had resolved disputes among themselves. Before the establishment of the westernized judiciary, Honolulu had a plural legal system, divided between theocratic and merchant justice. This division, as well as the presence of other forms

66. See Lâm, supra note 27, at 253-70.

67. See infra Part IV.

68. Lâm, for example, concentrates on working around the decision in Oni by reference to earlier laws establishing statutory rights for cultivators. See Lâm, supra note 27, at 270-72, 27576. 
of dispute resolution such as indigenous tribunals ${ }^{69}$ and mediation by visiting naval commanders, ${ }^{70}$ made it unsurprising that the monarchy would seek to meet foreign demands through the creation of a new legal system. Given a context in which pluralism was a fact of life, it seems unlikely that the monarchy would anticipate that their new courts would assert dominance over all other systems.

\section{A. Foreigners in Honolulu}

The missionaries were but one component of a foreign community in Honolulu that grew in numbers throughout the $1830 \mathrm{~s}^{71}$ One scholar estimates a growth from 180 in 1831, to between 500 and 600 in 1843, of which perhaps 100 were transients, either deserters or disabled sailors. ${ }^{72}$ Urbanization, the consumption of luxury goods by the ali $i$ (aristocrats), and the increasing number of whaling ships also financed a parallel growth in the number of foreign trading firms in Honolulu, from eleven in 1831 to twenty-four in $1840 .^{73}$ Hawai 'i's economy underwent vast fluctuations, depending in large part on its dominant form of exchange at the time. Kamehameha III's reign coincided with Hawai'i's whaling era, which began with the first visits by whalers in 1819 , but reached its peak between 1843 and $18600^{74}$ Whaling had its drawbacks. While the visits of whaling ships were tremendously lucrative for local merchants, they were also an uncertain basis for livelihoods. ${ }^{75}$

The fundamental uncertainty of the whaling industry was, in turn, exacerbated by larger-scale economic fluctuations in the 1830s and 1840s. The period immediately preceding the establishment of a westernized judiciary was, by most economic measures, a depressed one. From 1832 on, trade was in an extended slump, made worse by the aftermath of the Panic

69. See Walter F. Frear, The Evolution of the Hawaiian Judiciary, in PAPERS OF THE HAWAIIAN HISTORICAL SOCIETY No. 7, at 1-6 (1894).

70. See Caroline Ralston, Grass huts and Warehouses: Pacific Beach COMMUNITIES OF THE NINETEENTH CENTURY 76, 113-16 (1977).

71. For a general history of Honolulu, see EDWARD D. BEECHERT, HONOLULU: CROSSROADS OF THE PACIFIC (1991). For a portrait of life in Honolulu in the late 1830s, see Richard A. Greer, Honolulu in 1838, 11 HAWAIIAN J. HIST. 3 (1977).

72. See BRADLEY, supra note 5, at 254-55; see also SAHLINS, supra note 8, at 106 (estimating the foreign population of Honolulu at midcentury to be around 600 ).

73. See SAHLINS, supra note 8 , at 105. Morgan, relying on missionary accounts, cites a total of 6 general, or commission merchants, and 11 shopkeepers maintaining 15 shops in 1844. See MORGAN, supra note 12, at 100 .

74. See KUYKENDALL, supra note 5, at 93, 306-07; SAHLINS, supra note 8, at 101-26. For a classic history of American whaling, see ALEXANDER STARBUCK, HISTORY OF THE AMERICAN WHALE FISHERY: FROM ITS EARLIEST INCEPTION TO THE YEAR 1876 (Argosy-Antiquarian Ltd. 1964) (1878).

75. A single ship was likely to spend between $\$ 800$ and $\$ 1500$ dollars per visit. See MORGAN, supra note 12, at 80. 
of 1837 , which slowed American trade in the islands. ${ }^{76}$ As a result, by 1840 , most merchants in Honolulu were enmeshed in debt relations with other merchants whose economic situations were equally precarious. More settled incomes, such as those from plantation farming, were, as we have seen, not to be found until later in the century. ${ }^{77}$

Despite its comparatively small size, the foreign community was neither unified nor harmonious. Merchants remained suspicious of the missionaries' intimacy with the ali $i$, their primary debtors. ${ }^{78}$ Missionaries, for their part, suspected the merchants of duping Hawaiians and forcing them into debt for useless baubles. ${ }^{79}$ These tensions were further aggravated by national conflicts that divided the Americans and the British. ${ }^{80}$ While Britain had refrained from taking formal control of the islands, expansion by France elsewhere in the South Pacific made their forbearance more tenuous. The French establishment of a protectorate in Tahiti in 1842 made this fear of British aggression more acute. ${ }^{31}$ Thus, when a new forum for dispute resolution appeared, there was no shortage of animosities to drive litigation.

\section{B. Forms of Justice}

Before the 1840 s, nonviolent or commercial disputes between foreigners rarely ended up in the Kingdom's courts. Foreigners, instead, resolved disputes among themselves, or waited for naval assistance. The opportunity for forum-shopping provided by the existence of both missionary- and merchant-established systems, however, served to destabilize each individual system and contributed to the eventual breakdown of norms governing where different types of disputes would be heard.

\section{Theocratic Justice}

Having adopted Christianity, the ali $i$ t turned to missionaries for help in drafting laws based on their new faith. Lawmaking was initially prompted

76. See BRADLEY, supra note 5 , at 217,265 .

77. See supra note 58 .

78. John C. Jones, the American consul, called the missionaries "canting" and "hypocritical." See DAWS, supra note 9, at 78.

79. See, e.g., JUDD, supra note 21 , at 14 ("[F]ortunes have been made by certain merchants in [the sandalwood trade], (honorable, of course, especially when the hand or foot was used on the scales!)").

80. See RALSTON, supra note 70, at 115-16.

81. See JEAN INGRAM BROOKES, INTERNATIONAL RIVALRY IN THE PACIFIC ISLANDS, 1800 1875, at 108-10 (1941); JUDD, supra note 21, at 170. 
by the need to control disorderly foreign sailors. ${ }^{82}$ As the 1820 s progressed, the Hawaiian monarchy, led by $\mathrm{Ka}$ 'ahumanu, repeatedly sought to proclaim laws based on the Ten Commandments. ${ }^{83}$ This was first proposed in December of 1825 , after the conversion of a number of highranking ali $i$, and was quickly met with opposition by the merchants of Honolulu. ${ }^{84}$ Supporters of the laws tried again in late $1827 .^{85}$ This time, five laws were proposed, and then eventually three were proclaimed (prohibitions on murder, theft and adultery). ${ }^{86}$ These moral strictures were reiterated in 1829 , in the famous "Cow Proclamation," which also formally extended the laws to foreigners resident in Hawai ${ }^{~} i{ }^{87}$ Various proclamations were put together in 1834 in a fifteen-page pamphlet that covered murder, theft, unlawful sexual intercourse, fraud and drunkenness. The pamphlet remained Hawai' 'i's basic law until the Constitution of $1840 .^{88}$

With encouragement from their missionary-advisors, the Hawaiian monarchy set out on a more ambitious course of constitutional creation at the end of the 1830s. The ali ' $i$ had requested the missionaries' assistance in locating a lawyer to help them, but the missionaries were unable to find anyone with legal training willing to come to the Kingdom. ${ }^{89}$ Instead, in 1838, William Richards, a former missionary now employed by the Hawaiian monarchy, set about teaching the ali' $i$ the basics of western-style politics and economics. ${ }^{90}$ Richards and the students at the Lahaina seminary drafted what was called Hawai'i's "Declaration of Rights," 91 proclaimed in

82. See KuYKendal, supra note 5, at 120-21; W.D. Westervelt, Hawaiian Printed Laws Before the Constitution, in HAWAIIAN HISTORICAL SOCIETY SIXTEENTH ANNUAL REPORT 39, 41 (1908). For a description of disorderly conduct by sailors, see Richard A. Greer, Trouble on the Waterfront, 22 HAWAIIAN J. HIST. 20, 27-28 (1988).

83. See JUDD, supra note 21 , at 56 ("[O]ur people have no printed code of laws, other than the Decalogue, which Kaahumanu thinks can not be improved.").

84. See KUYKENDALL, supra note 5, at 123-24.

85. These were sponsored by Ka'ahumanu again. See 1 REYNOLDS, supra note 3, at 185 ("Boli told me the Missionaries were teasing Kaahumanu to make Laws. He said, He and the King did not want to do it.") (entry of May 24, 1827).

86. See SAHLINS, supra note 8, at 72.

87. It was called the Cow Proclamation because it was issued in response to an incident in October 1829 in which Richard Charlton, the British consul, roped and dragged a Native Hawaiian into Honolulu in response to the killing of Charlton's cow, which had apparently trespassed on cultivated enclosures. See KUYKENDALL, supra note 5, at 126-29; Westervelt, supra note 82, at 47-48. For the full text of the proclamation, see RALSTON, supra note 70, app. 1 at 219.

88. See Frear, supra note 17, at 31-32.

89. See id. at 34 .

90. See William Richards' Report to the Sandwich Islands Mission on His First Year in Government Service, 1838-1839 (Letter from William Richards to ABCFM (May 1, 1839)), in FIFTY-FIRST ANNUAL REPORT OF THE HAWAIIAN HISTORICAL SOCIETY 65-69 (1942); 22 Levi Chamberlain, Journal, at 1 (entry of Aug. 3, 1837) (typescript on file with the Hawaiian Mission Children's Society, Honolulu).

91. Frear, supra note 17, at 34. Others called it Hawai'i's "Magna Charta." See, e.g., Rufus ANDERSON, THE HAWAIIAN ISLANDS: THEIR PROGRESS AND CONDITION UNDER MISSIONARY LABORS 238 (Boston, Gould \& Lincoln 1864). The dogged attempts of contemporaries to fit the Hawaiian judicial experience into a western-based model of progress through pre-determined 
1839. This declaration, together with the Constitution of 1840 , set the stage for the dramatic increase in litigation that was to trouble the government in the early 1840 s, a consequence that was unintended by its religious drafters, but of crucial import to subsequent Hawaiian history.

In the legal system of Kamehameha $\mathbb{I}$ (1810-1819), each island was under the authority of a governor, who was appointed by the King. While the King himself embodied the highest judicial and executive authority, each governor had his or her own island court. Beneath the governors' courts were district courts and tax courts. ${ }^{92}$ The Constitution of 1840 formalized the topmost level by organizing the King's court into a Supreme Court comprised of the King and other notables, but left the lower levels the same. ${ }^{93}$ Thus, foreigners in Honolulu who wanted to bring a case to court would have the option of going to the Governor of Oahu, Mataio Kekuanao'a.

Prior to 1840 , foreigners willingly brought criminal cases in Hawaiian courts. ${ }^{94}$ Foreigners were quick to use the Hawaiian government in cases involving theft or trouble-making sailors. Stephen Reynolds relates the rapid resolution of one such case: "A native came into the house deliberately took up Several pieces calico cotton \& $\mathrm{c}$ and marched deliberately off. One of the boys soon saw him selling the goods \& informed me. I took to the fort \& soon my goods came back." 95 In one famous instance of a violent dispute between foreigners, the residents insisted that Boki, then-governor of Oahu, hear the case. ${ }^{96}$ But commercial disputes between foreigners remained in foreign hands. After the passage of new laws in 1841, however, this avoidance of the Hawaiian courts would largely disappear. ${ }^{97}$

stages represents a faith in legal evolution typical of the 19 th century. $C f$. PETER STEIN, LEGAL EVOLUTION: THE STORY OF AN IDEA 122 (1980) (describing 19th-century ideas of legal evolution).

92. See Frear, supra note 69 , at 6-7.

93. See id. at 8-9.

94. See, e.g., Peter J. Nelligan \& Harry V. Ball, Ethnic Juries in Hawaii: 1825-1900, 34 SOCLAL PROCESS IN HAWAI, 113, 118-19 (1992) (describing an 1825 attempted homicide case involving Joseph Navarre and Captain Sistaire); id. at 120 (1827 assault case against John Lawler); id. at 121 (1832 murder case against Robert Bell, a seaman, for the killing of another seaman); see also 17 Chamberlain, supra note 90, at 13 (entry of Dec. 3, 1832) (Bell trial); id. at 29 (entry of Sept. 21, 1835) (manslaughter case); 3 Reynolds, supra note 3, at 152 (entry of Apr. 25,1831 ) (trial for theft); 4 id. at 559 (entry of Dec. 22, 1837) (trial of sailor for theft).

95. 1 REYNOLDS, supra note 3, at 231 (entry of July 18, 1828); see also 21 Chamberlain, supra note 90, at 3 (entry of Nov. 12, 1836) (relating resolution of similar theft case).

96. See 1 REYNOLDS, supra note 3, at 208 (entries of Dec. 18, 19, 20, 1827).

97. See infra Part III. 


\section{Merchant Justice}

Another form of justice is harder to track down: the system of arbitration and peer adjudication used by merchants to settle their disputes. Evidence of these cases exists in the journals of Stephen Reynolds, an American merchant and amateur lawyer who lived in Hawai' $i$ from 1823 until $1855 .{ }^{98}$ Reynolds' journals are by far the richest source of information on commercial and legal practice in Hawai ${ }^{\prime} i$ in the 1830s and 1840s. While Reynolds was highly opinionated and often expressed his distaste for other parties with invective and multiple exclamation points, his reports of the facts of cases are apparently reliable. Comparison of his accounts of cases with letters and journals written by others (including bitter enemies of Reynolds $^{99}$ ) describing the same cases reveals no variance in the basic facts or outcomes of cases. ${ }^{100}$

The arbitration described by Reynolds is part of a larger nineteenthcentury trend. David Langum notes in his study of legal practices among Anglo-Americans in Mexican-ruled California that "expatriate practices were rooted ... in the general popularity of commercial arbitration in the nineteenth century." ${ }^{101}$ Langum found a general procedural pattern by which each party selected one arbitrator, and the two arbitrators thus selected agreed on a third. ${ }^{102}$ Cases similar to those described by Langum also occurred on a regular basis among Honolulu merchants.

98. Reynolds's biography is discussed in 1 REYNOLDS, supra note 3, at ix-xii. For details of Reynolds's later years and his insanity resulting from lead poisoning, see David A. Ward, The Old Complaint of Stephen Reynolds, 7 HAwAIIAN J. HIST. 87 (1973). One 19th-century chronicler described him as a man "with an evident predilection for the study of the law, [who] was, in the absence of any educated attorney residing in the town, the person who was generally consulted on matters that were coming before the courts." Gorman D. Gilman, Streets of Honolulu in the Early Forties, THRUM's HawaIIAN ANNUAL 74, 78 (1904). Reynolds's journals record his eager study of the law. See 4 Reynolds, supra note 3, at 75 (entry of Jan. 5, 1834) ("Mr. John Ball gave me four volumes of Chancellor Kent's Commentaries."); 4 id. at 354 (entry of June 22, 1836) ("Reading Vattel on the Laws of Nations."); 5 id. at 380 (entry of Feb. 20, 1841) ("Reading Blackstone's commentaries."); $5 \mathrm{id}$. at 421 (entry of May 22, 1841) ("Received three booksStorys Equity-\& Agency-Sumners Reports.").

99. See, e.g., William Paty, Joumal (entry of Jan. 17, 1843) (on file with the Archives of Hawai'i, Honolulu Port Records, Series 104).

100. Compare THE CALIFORNIA DIARY OF FAXON DEAN ATHERTON, 1836-1839, at 117-18 (Doyce B. Nunis Jr. ed., 1964) (entry of Dec. 19, 1838) (Rasselas case), with 5 Reynolds, supra note 3, at 56-57 (entries of Dec. 18-24, 1838) (same); compare Paty, supra note 99 (entry of Jan. 18, 1842) (Espener auction), with 5 Reynolds, supra note 3, at 527 (entry of Jan. 18, 1842) (same); compare 23 Chamberlain, supra note 90, at 105-06 (entries of Dec. 16, 29, 1841) (French suit), with 5 Reynolds, supra note 3 , at 516 (entry of Dec. 29, 1841) (same); compare Helen P. Hoyt, The Wreck of the "Philosopher" Helvetius, 2 HAWAIIAN J. HisT. 69, 73-74 (1968) (Helvetius salvage case), with 4 Reynolds, supra note 3, at $195-96$ (entries of Dec. 29-31, 1834) (same).

101. David J. LANGUM, LAW and COMMUNITY ON THE MEXICAN CALIFORNIA Frontier 215 (1987).

102. See id. at 215-16. 
This arbitration took place against a backdrop of self-help remedies. Reynolds's entry for October 21, 1830 is typical of debtor self-help: "Capt. Meek went away without Settling any of his accounts with me ... !!!" 103 Creditors also demonstrated ingenuity. Reynolds relates his search for a book on February 7, 1829: “[] went up to see Mr Elliot and get Chamber's Dictionary of Arts \& Sciences but he refused saying Mr Green owed him, $\&$ he meant to keep them to pay for the interest as money was worth one hundred per cent!!" 104

The cases that did go to arbitration are the inverse of those involving foreigners before the Kingdom's courts; where the Hawaiian courts dealt with criminal matters, the merchants dealt almost exclusively with commercial-largely civil-matters. Many of the disputes involved ships' charters. ${ }^{105}$ Perhaps the single largest category of disputes arose from shipwrecks and centered on either salvage awards ${ }^{106}$ or ship repairs. ${ }^{107}$ Some disputes were less directly linked to shipping and concerned debts and contract agreements. ${ }^{108}$ In the one area of overlap with the Kingdom's courts, merchants also resolved libel and slander cases. ${ }^{109}$

The procedure of arbitrations varied. It ranged from the simplicity of sending a dispute to a third party for mediation to formalistic attempts to recreate common law court practice. There were few set rules: Even something as basic as not serving as an arbitrator in a case in which one had an interest was often observed more in the breach than in practice. ${ }^{110}$ Unanimity does not seem to have been required. ${ }^{111}$ Parties could veto

103. 3 Reynolds, supra note 3, at 101 (entry of Oct. 21, 1830).

104. 1 REYNOLDS, supra note 3, at 252 (entry of Feb. 7, 1829).

105. See, e.g., 22 Chamberlain, supra note 90, at 30 (entry of Aug. 27, 1838); 4 Reynolds, supra note 3, at 276-77 (entry of Oct. 10, 1835); 4 id. at 447 (entry of Feb. 28, 1837); 4 id. at 522 (entry of Sept. 8, 1837); 4 id. at 526-27 (entry of Sept. 25, 1837).

106. For a detailed account of one particular salvage case, including Reynolds's involvement in arbitrating the salvage claims, see Hoyt, supra note 100, at 73-74. The Helvetius ran aground on a reef off Waikiki beach in November 1834. Kamehameha II himself (an interested party) sat on the committee of arbitrators organized by Reynolds. Id. at 73; see also Paty, supra note 99 (entry of Apr. 6, 1842) (salvage case).

107. See, e.g., 3 Reynolds, supra note 3, at $42-43$ (entry of Mar. 16, 1830); 3 id. at 239 (entry of Mar. 17, 1832); 4 id. at 195 (entry of Dec. 29, 1834); 4 id. at 405 (entry of Nov. 16, 1836); 5 id. at 56 (entry of Dec. 18,1838 ).

108. See, e.g., THE CALIFORNIA DIARY OF FAXON DEAN ATHERTON, supra note 100, at 117 18 (entry of Dec. 19, 1838); 4 Reynolds, supra note 3, at 46 (entry of Oct. 14, 1833); 4 id. at 189 (entry of Dec. 10, 1834); 4 id. at 366 (entry of July 30, 1836); 5 id. at 189 (entry of Nov. 8, 1839).

109. See, e.g., 23 Chamberlain, supra note 90, at 35-36 (entry of Aug. 14, 1839); 5 Reynolds, supra note 3, at 149 (entry of Aug. 12, 1839).

110. See, e.g., Hoyt, supra note 100, at 73; 5 Reynolds, supra note 3, at 59 (entry of Dec. 26, 1838) ("Talked with him about taking agency for J.C. Jones-told him he ought not to set again as a referee-it was sitting on his own affairs.").

111. But see, e.g., 5 Reynolds, supra note 3, at 195 (entry of Nov. 22, 1839) ("Yesterday Henry Skinner said HE would not submit his arbitration to be decided by the Majority of Arbitrators-it must be unanimous!!!!!"). 
arbitrators whom they disliked. ${ }^{112}$ The number of arbitrators varied as well. Standard procedure was to have two, one nominated by each party. ${ }^{113}$ At times, this became three arbitrators, when the two originally picked could only come to an agreement with the assistance (or tie-breaking) of a third. ${ }^{114}$ Nor was three the limit. On occasion, three grew into four, ${ }^{15}$ and four grew into five. ${ }^{116}$ In particularly thorny or contested cases, parties occasionally agreed to send the dispute abroad for settlement. ${ }^{117}$ In the most formal arbitrations, procedure mimicked that of the common law, albeit with notable exceptions-party disqualification for interest, for example, was not observed. But witnesses were sworn and cross-examined, written documents were carefully scrutinized, and parties prepared statements of their positions. ${ }^{118}$ Arbitrators quibbled about the sufficiency of evidence. ${ }^{119}$

Faxon Dean Atherton, a California merchant, provides an account of a three-member, highly formalized arbitration. He appeared as a witness in a dispute between Eliab Grimes and the partnership of John C. Jones and Alpheus Thompson, and recorded the events in his diary:

There was a number of questions asked me. Among others, I was asked what the ginghams had sold for. I told them I had sold them generally speaking at $\$ 14$ to $\$ 15 \ldots$. Immediately on my making the statement Mr. Jones sprung up from the place he was sitting and asked me if I pretended to state such as a fact. I told him I knew it to be such and could prove it by memorandum books of my own. He then said that he knew better, that from the books of Mr. Thompson he could prove it was not so and said he that was willing

112. See, e.g., 5 id. at 189 (entry of Nov. 8, 1839) ("Pierce offered to leave it out to some of the Merchants here-But he would never allow that old villain, old Reynolds, to be on any reference!! go ahead.").

113. See, e.g., 4 id. at 405 (entry of Nov. 16, 1836) ("Mr Jones for Capt Chase \& $\mathrm{Mr}$ Biddlecome for Mr Chariton settled the Salvage of the property from Harmony.").

114. See, e.g., Paty, supra note 99 (entry of Apr. 6, 1842); 5 Reynolds, supra note 3, at 336 (entry of Nov. 14, 1840) ("Mr Couthany-Mr Ladd-two Referees, to choose third--F. J. Greenway.").

115. See, e.g., Greer, supra note 71, at 19; 4 Reynolds, supra note 3, at 526-27 (entry of Sept. $25,1837)$.

116. See, e.g., 23 Chamberlain, supra note 90, at 36 (entry of Aug. 14, 1839); 5 Reynolds, supra note 3, at 195 (entry of Nov. 22, 1839). Reynolds reflected on one such arbitration: "Had [the fourth arbitrator] agreed with [the third arbitrator], would a fifth [have] been called, or would it have gone back to the three-or would they have called a Sixth or a Seventh?" Letter from Stephen Reynolds to Alpheus B. Thompson (Sept. 26, 1837), quoted in David Ward, Unpublished Notes to 4 Reynolds Joumal 116-18 (on file with the Hawaiian Mission Children's Society, Honolulu).

117. See, e.g., 4 Reynolds, supra note 3, at 530-31 (entry of Oct. 9, 1837) ("H A Peirce gave E Grimes and Co-Jules Dudoit papers to go Boston to the Referees."); 5 id. at 307 (entry of Aug. 29, 1840).

118. For an example of a case involving all of these, see 5 id. at 195 (entry of Nov. 22, 1839).

119. See 5 id. at 150-51 (entry of Aug. 14, 1839). 
to take oath to that effect and that he desired that the oaths of all witnesses might be taken. ${ }^{120}$

Atherton records a procedure that involved cross-examination of witnesses by parties and a demand for oaths. Thompson's insistence on production of the memorandum book is also typical of arbitration procedure, in which all the documents were turned over to the arbitrators.

Was merchant justice able to produce compliance? Clearly, the system was not wholly effective. ${ }^{121}$ Certain irascible parties, such as J.O. Carter, Henry Skinner, and Richard Charlton, could derail the process by refusing to comply. Their actions, however, were met with disapprobation. Reynolds noted of Skinner's seizure of disputed goods: "Mr Skinner is the first person-who undertook to take the Law \& property into his own hands-I look upon it as an insult to every Resident. It is to be hoped every intelligent person will take all just measures to stop and put down club law." 122 Reynolds exaggerated the novelty of Skinner's actions. But his hyperbole reflects the importance of norms of compliance to the Honolulu business community. Those norms, however, were about to undergo a striking change.

\section{TAKING IT TO COURT}

Virtually all commentators point to the importance of the adoption of a western-style legal system in Hawai' $i$-either as a mark of progress or as a coercive instrument that later enabled western domination of Hawaiian land and labor. ${ }^{123}$ Their explanations for why this change came about vary. Recent scholarship sees adoption as a strategic defense against colonialism. ${ }^{124}$ Sally Merry, a prominent scholar of Hawaiian anthropology and history, characterizes the adoption of a western legal system as "a resistant appropriation," 125 by which the Hawaiian monarchy cannily gained international legitimacy for the Kingdom by adopting a westernstyle legal system.

Another explanation links the adoption to international tensions among foreign residents. Imperial expansion fueled mutual mistrust among the

120. See The CALIFORNIA DiaRY OF FAXON DEAN ATHERTON, supra note 100, at 117-18.

121. See, e.g., 4 Reynolds, supra note 3, at 527 (entry of Sept. 26, 1837) ("J.O. Carter refused to comply with the Referees decision.").

122. 4 id. at 432 (entry of Jan. 25,1837 ).

123. See, e.g., KUYKENDALL, supra note 5, at 227; Frear, supra note 92, at 25; Merry, supra note 25 , at 595 .

124. This is a revisionist version of the traditional explanation of monarchy's decision. That explanation centered on the disinterest, or incompetence, of the Hawaiian monarchy in overseeing the Kingdom's legal affairs. Not understanding western law, they handed their court system over to foreign management. See SAHLINS, supra note 8, at 101.

125. Merry, supra note 25, at 602. 
French, British, and American residents of Honolulu, ultimately leading to an outpouring of litigation. This was the explanation most favored by contemporaries. George Simpson, director of the Hudson's Bay Company and a visitor to the islands in 1842, noted "one half of all the strangers in this strange land are not on speaking terms with the other." ${ }^{126}$

All of these explanations are parts of the story. Yet they do little to explain why the shift happened at a particular moment. The threat (or prospect) of annexation remained part of the Hawaiian scene from Captain Cook's visit in 1778 until the eventual U.S. annexation in $1898 .{ }^{127}$ Similarly, evidence for national tensions can be found as early as the $1820 \mathrm{~s} .{ }^{128}$ And national tensions do not explain the pattern of litigation. One of the most contentious suits, for example, was between George Pelly and Richard Charlton, both British citizens. Such explanations are popular because they fit in well-retrospectively-with the British takeover of Hawai' ${ }^{\circ}$ in $1843 .{ }^{129}$ As I will show, however, new laws and the upsurge in litigation preceded (and even caused) the abortive British occupation.

Instead, to understand the shift, we need to focus on the specific events of the early 1840 s, particularly the passage of new laws. The solution to the puzzle of why merchants turned to the courts helps to explain the larger question of why the western-style judiciary was adopted.

\section{A. The Laws of $1841^{130}$}

Following the Constitution of 1840 , the new House of Nobles passed additional laws, which provided the islands with their first comprehensive "law code" covering both commercial and criminal matters. ${ }^{131}$ Much like the Constitution itself, the laws are works by Hawaiians that bear pronounced indications of missionary inspiration. The Polynesian, Honolulu's English-language, government paper, celebrated them as "a

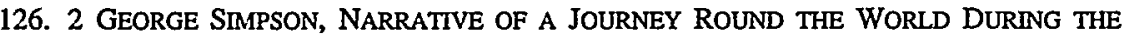
YeARS 1841 AND 1842, at 158 (London, Colburn 1847). The entry of the Hudson's Bay Company into the Honolulu market in 1834 heightened tensions between Americans and British. For more on the Company, see Alexander Spoehr, A 19th Century Chapter in Hawai ' $i$ 's Maritime History: Hudson's Bay Company Merchant Shipping, 1829-1859, 22 HAWAIIAN J. HIST. 70 (1988).

127. See generally BROOKES, supra note 81 (describing rivalry among western nations).

128. Reynolds frequently refers to the fervor of July 4 celebrations in Honolulu. See, e.g., 1 REYNOLDS, supra note 3, at 142 (entry of July 4, 1825).

129. See infra Part IV.

130. These laws are generally referred to as the laws of 1842 , after the date of their publication in English translation in Lahaina. However, many of the laws in question were actually passed in 1841. See TRANSLATION OF THE CONSTITUTION AND LAWS OF THE HAWAIIAN ISLANDS, ESTABLISHED IN THE REIGN OF KAMEHAMEHA III (Lahainaluna, Hawai'i, William Richards trans. 1842), reprinted as THE FUNDAMENTAL LAWS OF HAWAII (Lorrin A. Thurston ed., The Hawaiian Gazette Co., Ltd. 1904) (1842) [hereinafter FUNDAMENTAL LAWS].

131. See Frear, supra note 17, at 42-44. For a contemporary Hawaiian account of lawmaking, see SAMUEL M. KAMAKAU, RULING CHIEFS OF HAWAII 369-78 (1961). 
very respectable body of laws; perhaps as well adapted to the present wants of the nation as any other that could be devised." 132

Some of the most important provisions of the new laws dealt with jury selection. A jury was required for all cases involving fines or damages of more than one hundred dollars. ${ }^{133}$ Foreign juries were allowed to be as small as eight members, given the difficulty in assembling them. ${ }^{134}$ If both parties in a case were foreigners, then the entire jury was to be comprised of foreigners; if one party was Hawaiian, then the jury was to be half foreign, half Hawaiian. ${ }^{135}$ (Special provision was made for French parties, whose juries were to be formed according to the LaPlace Treaty guaranteeing consular selection of juries. ${ }^{136}$ ) These provisions essentially codified preexisting practice, which called for foreign juries for foreign parties, even though finding foreigners willing to sit on juries proved difficult at times. ${ }^{137}$

Although commercial relations were not the main focus of the laws, provisions were included dealing with partnerships, ${ }^{138}$ bailments, ${ }^{139}$ and debt. ${ }^{140}$ For the first time, debt relations were regulated by the Hawaiian government. The provisions governing debt held that, in the absence of a note specifying the terms of the debt, interest was to be set at one per cent per month. This rate was to apply to all debts that were past due as well. ${ }^{141}$ The law also provided for hard labor for fraudulently contracted debts, or for "one [who] becomes famous on account of his frequently contracting debts and not paying them, and [has] no property with which to pay." ${ }^{142}$ One absence, however, stands out. None of the laws explicitly addressed the problem of bankruptcy. By omission, the laws provided only for regular debt collection procedures in the case of bankruptcy, procedures that were premised on the assumption of a single creditor. This omission was to cause a race among debtors of possible bankrupts to be the first to file their suits.

Another innovation gave judges the power to attach property in debt disputes. The "Law Respecting Debtors" said that if "the creditor becomes

132. THE POL YNESIAN (Honolulu), Oct. 23, 1841, at 73.

133. See Fundamental LAws, supra note 130 , at 115 (Ch. XIVII, A Law for the Regulation of Courts.).

134. See id. at 118 .

135. See id. at 120.

136. See id. This privilege was extended to the British in 1844. See KUYKENDALL, supra note 5 , at 231 .

137. Jury avoidance predated the passage of the jury laws. See, e.g., 5 Reynolds, supra note 3, at 313 (entry of Sept. 17, 1840) ("I called down to see the Governor [whose Fort also housed the jail and the courthouse]-came away lest I should be asked to set on the jury to try Yankee Jim.").

138. See FUndamental Laws, supra note 130, at 77-78 (Ch. XXIV, Law Respecting Partnerships) (enacted Sept. 1, 1841).

139. See id. at 71-72 (Ch. XX, Law Respecting Property in Trust) (enacted Sept. 1, 1841).

140. See id. at 66-67 (Ch. XVI, Laws Respecting Debts and Usury) (enacted Sept. 1, 1841).

141. See id.

142. Id. at 74 (Ch. XXII, Law Respecting Debtors) (enacted Sept. 1, 1841). 
anxious and fear lest he should not obtain the debt, he may then go to either of the judges who will thereupon attach the property of the debtor." 143 If the debt was not paid within thirty days of the attachment, the law authorized the judge to sell the property at auction, although there was a clause allowing debtors "suffering some misfortune from the providence of God" ${ }^{144}$ up to a year to repay. This law quickly became popular and created so many problems that the legislature soon passed an amendment holding the plaintiff responsible for "any subsequent difficulty in consequence of the attachment having been wrongfully made." ${ }^{145}$

\section{B. Merchant Responses}

Honolulu's merchants knew about the new laws. Reynolds was aware of the proposed laws before they were passed: "New Laws to be promulgated in a few days. Some severe ones." ${ }^{146} \mathrm{He}$ then noted on August 17,1841 that new laws had been announced and attributed them to the missionaries. ${ }^{147}$ Once they had been translated, he sought out Richards for a copy: "Called down to see Mr. Richards about the Laws .... Mr. Richards lent me a copy of the Native Laws in English—and a Manuscript copy of the jury Laws-in English-some bad features." 148 Other merchants vehemently opposed the new laws. Alexander Simpson ${ }^{149}$ called them "a mixture of the Puritanism of the Blue Laws of Connecticut with a power given to officers to practice extortion and tyranny that is not possessed by a Turkish Pacha [sic]." 150

Despite this professed distaste, the shift that followed the passage of the laws was striking. Merchants used the new provisions to badger their debtors and, ultimately, to enforce the dispersal of their bankrupt colleagues' assets. The new laws came at a time when merchants had just begun to use recourse to Hawaiian courts as a bargaining tactic. The previous November had seen a jury assembled to hear a case concerning a shipment of tallow, but the parties later agreed to arbitration. ${ }^{151}$ One case was actually heard through to its conclusion before the passage of the new

143. Id

144. Id. at 75 .

145. Id. at 132 (Ch. LIII, Amendments to Law XXII) (enacted May 16, 1842).

146. See 5 Reynolds, supra note 3 , at 432 (entry of June 12, 1841).

147. See 5 Id. at 456 (entry of Aug. 17, 1841).

148. 6 Id. at 15 (entry of May 27, 1842).

149. He was the cousin of George Simpson, who was mentioned supra text accompanying note 126.

150. AlEXANDER SIMPSON, THE SANDIICH ISLANDS: PROGReSS OF EVENTS SINCE THEIR DISCOVERY BY CAPTAIN COOK 40 (London, Smith, Elder 1843).

151. See Nelligan \& Ball, supra note 94, at 125; Paty, supra note 99 (entry of Jan. 3, 1842); 5 Reynolds, supra note 3, at 336 (entry of Nov. 14, 1840) ("The great Tallow Case at the Fortafter the Jury assembled-was taken out of court and settled by Reference."). 
laws, but because it involved a dispute between an American and a Chinese merchant, it may reflect racial divisions among foreigners as much as changing practice. ${ }^{152}$ In contrast to these tentative beginnings, the turn to the Kingdom's courts following the enactment of the new laws was much more decisive.

The shift to Kingdom courts in the year or so following the new laws on debt was extensive. In the three months remaining in 1841, four suits were brought in Kingdom courts on commercial matters. In 1842, another eight suits were brought. ${ }^{153}$ While in absolute terms, twelve suits may appear trivial, that number must be compared to a previous maximum of five recorded arbitrations in a single year and a history of only two such cases employing the Kingdom courts in the history of Honolulu before that point. ${ }^{154}$ Not only were lawsuits now more popular than arbitration, they were also more frequently used than arbitration had ever been.

The new power of attachment also proved popular. Another Hawaiian merchant, William Paty, noted in his journal in January 1842 that:

Today we have had something new for Oahu, a Sherriff's [sic] Sale, the first that ever took place at the Sandwich Islands. Dr. Espener's goods, \& chattels were sometime since laid under attachment by the governor at the instance of J-R-n and were this day sold at public Auction. So we advance in civilization. ${ }^{155}$

Reynolds sounded a similar note at another auction: "Doct. Tresilian called his Creditors together yesterday. He owes 1425 . dollars-700 to E[liab] \& $\mathrm{H}[\mathrm{iram}]$ Grimes-to pay which he has a Gally-Pot, a few phials of colored water, Boxes Pills, or rather Pill Boxes, \& no Pills. His Beggarly ayr [sic] reminded me of the apothecary in Hamlet." ${ }^{156}$

By 1842, Reynolds was bemoaning the legalization of Honolulu: "Sueing folks is the order of the day now. The smaller the Debt, the more certain of being sued! Rapid civilization!" ${ }^{157}$ Even minor debts were sued

152. See 5 Reynolds, supra note 3 , at 443 (entry of July 16,1841 ).

153. Fewer suits were brought in 1843, but for half of that year Hawai' $i$ was under British occupation. See infra text accompanying notes 195-201.

154. For the two cases, see 1 ReYNoLDS, supra note 3, at 204-05 (entries of Nov. 19, 26, 1827); and 5 id. at 443 (entry of July 16,1841 ).

155. Paty, supra note 99 (entry of Jan. 18, 1842). Stephen Reynolds recorded the same event. See 5 Reynolds, supra note 3, at 527 (entry of Jan. 18, 1842); see also Chamberlain, supra note 90 (entry of Dec. 29, 1841) (judgment against Espener); Paty, supra note 99 (entry of Dec. 3, 1841) (sheriff's auction).

156. Letter from Stephen Reynolds to Thomas Oliver Larkin (July 3, 1842), in 1 THE LARKIN PAPERS: PERSONAL, BUSINESS, AND OFFICIAL CORRESPONDENCE OF THOMAS OLIVER LARKIN, MERCHANT AND UNITED STATES CONSUl IN CALIFORNIA 245 (George P. Hammond ed., 1951) [hereinafter LARKIN PAPERS]. For examples of other auctions, see Chamberlain, supra note 90 (entries of Dec. 2, 1842, Apr. 8, 1844).

157. Letter from Stephen Reynolds to Thomas Oliver Larkin, supra note 156, at 245. 
on. ${ }^{158}$ A watchmaker was sued in December 1841 for selling a watch that had been left for repairs and never reclaimed. ${ }^{159}$ A settlement offer in a suit between Jules Dudoit and Eliab Grimes reflects the broad acceptance of the new practice. Dudoit proposed to settle the dispute by suing a third party for salvage claims and turning over the proceeds of the suit to Grimes, in exchange for a note from Grimes. Despite Reynolds's opposition, Grimes agreed to this course of action. ${ }^{160}$

\section{Three Cases}

The extent to which Honolulu's commercial community had become legally oriented by the mid-1840s can be judged by closer examination of three cases, selected both for their representativeness of the general climate and for their importance in changing disputing practices among foreigners in Hawai'i.

\section{Skinner-Dominis Suit}

Richard Charlton, ${ }^{161}$ the British consul, had advised Henry Skinner not to go to Hawaiian courts: "I shall always be sorry," he wrote Skinner, "to make any appeals to this Government in cases of this kind, as I do not consider any native tribunal qualified to decide the merits of such cases ...." ${ }^{162}$ John Dominis had refused to submit the case to arbitration in Honolulu, proposing Macao as an alternative location. ${ }^{163}$ Skinner rejected the offer angrily, threatening to "take decisive steps to recover my property, by, measures [that] must be obnoxious to both ourselves and this community ...." 164 To which Dominis responded, rather airily, "Your bravado and threats excite no feeling but that of contempt." ${ }^{165}$ With that,

158. See, e.g., 6 Reynolds, supra note 3 , at 32 (entry of June 30,1842 ).

159. See 5 id. at 513-14 (entry of Dec. 23, 1841).

160. See 5 id. at 542-44 (entries of Feb. 17-19, 21, 22, 1842).

161. For a recounting of Richard Charlton's career, see Richard MacAllan, Richard Charlton: A Reassessment, 30 HAWAIIAN J. HrST. 53 (1996). For a contemporary view of Charlton, see Letters from G.P. Judd to R.C. Wyllie (Feb. 15, 1845), reprinted in KINGDOM OF HAWAII, CORRESPONDENCE BETWEEN H.H.M.'S SECRETARY OF STATE FOR FOREIGN AFFAIRS AND HER BRITANNIC MAJESTY'S CONSUL-GENERAL ON THE SUBJECT OF RICHARD CHARLTON'S Claim to LAND 113 (Honolulu, Government Press 1845) (calling Charlton "the ever fruitful cause of lawsuits and political turmoil in this nation").

162. Letter from Richard Charlton to Henry Skinner (Sept. 28, 1841), in CORRESPONDENCE, supra note 11, at 104, 104.

163. Letter from John Dominis to Henry Skinner (Sept. 17, 1841), in CORRESPONDENCE, supra note 11 , at 115,115 .

164. Letter from Henry Skinner to John Dominis (Sept. 27, 1841), in CORRESPONDENCE, supra note 11 , at 118,118 .

165. Letter from John Dominis to Henry Skinner (Sept. 28, 1841), in CORRESPONDENCE, supra note 11 , at $119,119$. 
correspondence between the two ceased and Skinner proceeded to sue Dominis in the Court of Oahu.

Skinner and Dominis's exchange is revealing for two reasons. First, its pugnaciousness and heated personal animosity demonstrate that this was an extreme case. In other circumstances, the norms dictating submission to arbitration, alluded to in Skinner's comment on his measures being obnoxious to their community, almost certainly would have kept the case out of the courts. The second noteworthy aspect of their exchange is Skinner's conviction that there was the possibility of enforcing the contract in the Hawaiian courts. Here we see both the strength of the old norms and the temptation provided by the laws of 1841 as an alternative means of enforcement. ${ }^{166}$

\section{French-Greenway Bankruptcy}

What was extreme in the Skinner-Dominis case quickly became routine. Individual suits soon generated countersuits. The most notorious fountainhead of litigation was a second case, the William French-Francis Greenway bankruptcy, which dragged on until 1845, becoming Honolulu's Jarndyce and Jarndyce. ${ }^{167}$ In early 1842 , Greenway, a British merchant, announced his bankruptcy. Reynolds, Skinner, and Simpson were appointed his assignees. Shortly thereafter, to their surprise, French, an American trader, announced that he was Greenway's silent partner and then declared his own bankruptcy, appointing as assignees Reynolds and William Ladd, an American merchant with close ties to the mission. Reynolds then fought with Skinner and Simpson. ${ }^{168}$ Matters were further complicated by French's alcoholism ${ }^{169}$ and Greenway's insanity. ${ }^{170}$ In 1844 , Greenway was declared insane by a jury that cited, among other evidence, his "inapposite quotations from Shakespeare." ${ }^{171}$ Afterwards, his property was distributed by an agent of the court. In a final irony, investigation of their accounts showed that Greenway and French had never actually been bankrupt, only financially embarrassed. ${ }^{172}$

166. Ironically, the parties in the Skinner-Dominis case were ultimately forced to resort to arbitration. After Skinner refused to recognize the jury, the suit remained unresolved until 1842, when the visiting director of the Hudson's Bay Company, George Simpson, worked out a settlement. See KUYKENDALL, supra note 5, at 209; 2 SIMPSON, supra note 126, at 158-59.

167. Jarndyce and Jarndyce is the name of the long-running chancery suit in Charles Dickens's Bleak House, which drives many of its participants to insanity or to their graves. See CHARLES DiCKENS, BLEAK HOUSE (Bantam Classics 1983) (1853).

168. See BRADLEY, supra note 5 , at 425 n. 130 .

169. See, e.g., 5 Reynolds, supra note 3, at 560 (entry of Apr. 10, 1842).

170. See Paty, supra note 99 (entry of Apr. 5, 1843) (calling Greenway "partially insane").

171. THE POLYNESIAN (Honolulu), May 18, 1844, at 2.

172. See KUYKENDALL, supra note 5 , at 245. 
Along the way, however, the supposed French-Greenway bankruptcy generated a torrent of litigation. Skinner and Simpson started the flood by attempting to sue French for what he owed Greenway, but the Governor refused their suit because they would not let it go before a jury. ${ }^{173}$ Reynolds had previously opposed the rush to litigate, arguing that Charles Brewer should refrain from suing Greenway. ${ }^{174}$ But, as the conflict with Skinner and Simpson escalated, he too went to court and successfully sued Greenway for the amount owed to him. Greenway's property was attached and held for auction. ${ }^{175}$ Meanwhile, Hiram Grimes sued Skinner and Simpson, and Jules Dudoit sued Reynolds in his capacity as French's trustee, on behalf of the Catholic mission. ${ }^{176}$ This profusion of litigation demonstrates the fragility of the new system in the face of interlocking debt relations and the dangers posed by a race to litigation set off by the initial success of a few plaintiffs. The multiple suits prompted by the FrenchGreenway bankruptcy persisted for years after the initial declaration of insolvency and ultimately required personal intervention by Hawai'i's new attorney general before they were finally concluded in $1845 .{ }^{177}$

\section{Pelly-Charlton Suit}

A third case, which involved a smaller number of participants, but which was just as consequential, was George Pelly's debt recovery suit against Charlton. Shortly after Charlton's departure from Honolulu in 1842, Pelly, an agent for the Hudson's Bay Company, sued Charlton for the recovery of a debt owed to a British firm in Valparaiso. The assembled jury found for Pelly and assessed almost $\$ 5000$ in interest on the unpaid debt. Afterwards, the government attached Charlton's property but did not proceed to an auction, probably for fear of Charlton's litigious temper. ${ }^{178}$ British residents were outraged by the government's actions against Charlton-despite the fact that Pelly himself was also British-and disputed the government's right to settle commercial disputes. The acting British consul wrote a letter describing the case to British naval officers in Mexico, which prompted the ordering of George Paulet to the Hawaiian islands, ultimately leading to the cession of the islands to Britain.

173. See BRADLEY, supra note 5 , at 425 n. 130 .

174. See 5 Reynolds, supra note 3 , at 551 (entry of Mar. 9, 1842).

175. See Paty, supra note 99 (entry of Apr. 23, 1842); 6 Reynolds, supra note 3, at 60-63, 6671 (entries of Aug. 25-27, 29, Sept. 6-10, 12, 1842); Letter from Stephen Reynolds to Thomas Oliver Larkin (Sept. 29, 1844), in 2 LARKIN PAPERS, supra note 156, at 246.

176. See Paty, supra note 99 (entries of Nov. 27, 28, 1844); 6 Reynolds, supra note 3, at 146, 150-51 (entries of Feb. 9, 15, 1843).

177. See THE PolyneSIAN (Honolulu), Apr. 12, 1845, at 191.

178. See BRADLEY, supra note 5, at 424; DAWS, supra note 9, at 113-14; KuYKENDALL, supra note 5, at 211-12. 
Pelly's case is significant for a number of reasons. First, it demonstrates that nationality is an uncertain guide for understanding the pattern of litigation. ${ }^{179}$ In addition, it shows the extent to which resort to the Kingdom's courts had become routinized within the first few years after Skinner's case. Finally, it was the precipitating event in the Paulet episode, ${ }^{180}$ which became the greatest threat to Hawaiian sovereignty before the American annexation.

\section{Motivations}

What emerges from the records of these cases is a combination of what might be called rational and irrational motivations. Merchant decisions to litigate drew upon both cost-benefit analyses and a more elusive affection for the trappings of legality. This combination sheds light on the limits of extra-legal dispute resolution. Scholars recently have directed their attention to the role of community norms and alternative dispute resolution processes as viable alternatives to litigation. ${ }^{181}$ Somewhat less attention, however, has been paid to the conditions under which such alternative systems are abandoned. Robert Ellickson, one of the most prominent students of this question, identifies four factors that govern the shift to the formal legal system: (1) the nature of the relationship between the parties; (2) the size of the stakes; (3) the content of the dispute; and (4) the possibility of externalizing costs to a third party. ${ }^{182}$

In several ways, the Hawaiian experience supports Ellickson's model. Merchants in Hawai' $i$ acted rationally by responding to the opportunity to externalize enforcement costs to the Hawaiian government, taking advantage of its new power of attachment. The high stakes in some cases clearly drove a rush to the courts as well. Merchants were also somewhat sensitive to their future relationships with other parties, reserving many of their harshest attacks for those who apparently were leaving the economic scene for good. ${ }^{183}$

179. In another example of alliances across nationality, Reynolds opposed the verdict in the slander case and urged Charlton to appeal. See 6 Reynolds, supra note 3, at 393-94 (entries of June 19, 20, 1844).

180. See infra Part IV.

181. See, e.g., Jerold S. Auerbach, Justice Without LAW? (1983); ROBERT C. ELLICKSON, ORDER WITHOUT LAW: HOW NEIGHBORS SETTLE DisPuTES (1991); 1 THE POLITICS OF INFORMAL JUSTICE: THE AMERICAN EXPERIENCE (Richard L. Abel ed., 1982).

182. See ELLICKSON, supra note 181, at 256-58.

183. For an intriguing modern parallel, see Lisa Bernstein, Merchant Law in a Merchant Court: Rethinking the Code's Search for Immanent Business Norms, 144 U. PA. L. REV. 1765, 1796-1802 (1996), who argues that merchants distinguish between relationship-preserving and end-game situations and adjust their norms accordingly. 
The role of bankruptcy was central in all of this. ${ }^{184}$ Many debt suits were generated out of comparatively few instances of bankruptcy. Bankruptcy not only provoked suits against the bankrupt parties themselves, but also against their assignees and business associates. By October 1842, Reynolds was predicting general failure: "Bankruptcy \& ruin stareing [sic] all in the face." ${ }^{185}$ Tellingly, in a letter to an associate, Reynolds mistakenly called the debt laws "the Bankrupt Law." 186 The turn to Hawaiian courts in cases of bankruptcy is consistent with the Ellicksonian model: The stakes were high, and creditors had little expectation of future dealings with the bankrupt parties.

Rational calculation of benefits was not the only factor involved, however. While potential profit to be gained by use of the new legal system seems to have been a key motive, it alone cannot explain the rush to law. Opportunities for less expensive out-of-court settlement were rejected when they arose, as the cases above show. ${ }^{187} \mathrm{~A}$ desire for the form of legality was at work as well. ${ }^{188}$ Langum notes a similar phenomenon among merchants in California, who sought legally meaningless ratification of their contracts with the local alcalde (district judge), despite the fact that such contracts were unenforceable. ${ }^{189}$ He explains this by reference to what John Reid calls the "behaviorism" of law. ${ }^{190}$ Reid argues that nineteenth-century American society demonstrated a surprising level of popular awareness of and conformance with law, regardless of levels of enforcement. In Hawai' $i$, merchants showed a similar affection for the rhetoric of law. Skinner proclaimed his hopes for "enforcing justice." ${ }^{191}$ Reynolds's persistent collection of law manuals speaks to his abiding interest in the forms of legality ${ }^{192}$ Merchants, in other words, sought legal settlements out of a conviction of their propriety and legitimacy, even when it was not economically beneficial for them to do so.

184. Hawai' $i$ was not alone in its inability to deal with the business failures following financial panics. For similarly ineffectual responses by U.S. state legislatures to the Panic of 1837, SEe PETER J. COLEMAN, DEBTORS AND CREDITORS IN AMERICA 50, 78, 84 (1974).

185. 6 Reynolds, supra note 3 , at 94 (entry of Oct. 27, 1842).

186. Letter from Stephen Reynolds to Thomas Oliver Larkin (Nov. 3, 1842), in 1 LARKIN PAPERS, supra note 156, at 307 ("Business awful every one taking benefit of the Bankrupt Lawno confidence in any one.").

187. See, e.g., 5 Reynolds, supra note 3, at 551 (entry of Mar. 9, 1842).

188. At times, hypocritically. Reynolds records the contempt one of the chief litigators, George Pelly, felt for the Hawaiian laws: "Pelly said HE would not observe any Law unless he saw fit." 5 Reynolds, supra note 3, at 541 (entry of Feb. 14, 1842).

189. See LANGUM, supra note 101, at 172-74. But see MORRIS S. ARNOLD, UNEQUAL LAWS UNTO A SAVAGE RACE: EUROPEAN LEGAL TRADITIONS IN ARKANSAS, 1686-1836 (1985) (describing the relative lack of importance of legality to settlers in colonial Arkansas).

190. JOHN PHILlip REID, LAW FOR THE ELEPHANT: PROPERTY AND SOCIAL BEHAVIOR ON THE OVERLAND TRAIL 11 (1980).

191. Letter from Henry Skinner to Richard Charlton (Sept. 29, 1841), in CORRESPONDENCE, supra note 11 , at 105,105 .

192. See supra note 98. 
This affection for legality was bolstered by a simultaneous trend toward formalization. ${ }^{193}$ Bruce Mann describes a similar progression in colonial Connecticut whereby "[o]nce-neighborly modes of disputing yielded to a legal system that treated neighbors and strangers alike." ${ }^{194}$ Hawai' $i$ is an extreme example of the trend Mann explores, since the global nature of its commerce had necessitated that even strangers (i.e., people living in Boston, Valparaiso and Canton) were trusted as neighbors in business transactions. By the mid-1840s, however, real neighbors, longtime residents of Honolulu, were being hauled into court and sued by other residents. In addition, formalization occurred within arbitration. Procedurally ornate arbitrations-with six arbiters, formalized rules of evidence, and bondsbecame increasingly common as the $1830 \mathrm{~s}$ progressed. As merchants became accustomed to jury-like panels of arbitrators, such cases perhaps provided a bridge to acceptance of jury trials in the Kingdom's courts. Formalization of arbitration made it easier for merchants to switch to the Kingdom's courts, because it reduced the differences between legal fora.

\section{THE INCREASING CAUCASIAN ROLE IN GOVERNMENT}

The consequences of this flurry of litigation were more dramatic than anyone could have predicted. Not only did it provoke a crisis of Hawaiian sovereignty, but it also spelled the end of a plural legal system. For five months in the spring and summer of 1843 , Hawai' $i$ became a British possession-the British flag flew over Honolulu and British officers ruled Hawai $i$. The roots of this temporary cession lie within the litigation that had occurred over the preceding year and a half. ${ }^{195}$ As W.F. Frear comments: "It was largely owing to some of the cases that came before [the Court of Oahu] that Lord George Paulet... made the demands which brought about the provisional session [sic] of the Islands ...." 196 British residents of Honolulu, under Charlton's irascible leadership, compiled a list of grievances resulting from the conduct of the new courts. ${ }^{197}$ Charlton then

193. For an analogous phenomenon in colonial America, see Bruce H. Mann, The Formalization of Informal Law: Arbitration Before the American Revolution, 59 N.Y.U. L. REV. 443 (1984).

194. BRUCE H. MANN, NEIGHBORS AND STRANGERS: LAW AND COMMUNITY IN EARLY CONNECTICUT 10 (1987).

195. James Jackson Jarves, editor of the Polynesian, attributed the cession to law cases decided unfavorably toward British residents. See JAMES JACKSON JARVES, HISTORY OF THE HAWAIAN ISLANDS 173 (Honolulu, Charles Edwin Hitchcock 1847); see also KUYKENDALL, supra note 5, at 206-10 (noting contentious cases). For Jarves's work with The Polynesian, see Helen Geracimos Chapin, Newpapers of Hawai ${ }^{\prime} i$ 1834 to 1903, 18 HaWAחAN J. HisT. 47, 59-60 (1984).

196. Frear, supra note 69 , at 14.

197. These included the Skinner-Dominis case, the Greenway bankruptcy, and Charlton's own land claim. See KUYKENDALL, supra note 5, at 208-09; Richard MacAllan, Sir George 
departed for England, where he planned to bring their complaints to the attention of the British government. On the way, he met with Lord George Paulet, a naval commander stationed in Mexico. When more complaints followed, this time forwarded by Simpson, ${ }^{198}$ the acting British consul in Charlton's absence, Paulet's commanding officer, Rear Admiral Richard Thomas, ordered him to Honolulu. Paulet seized Hawai'i for the British crown on February 15, 1843. ${ }^{199}$ The British remained in charge in Honolulu until July, when Admiral Thomas arrived to restore sovereignty to Kamehameha $\mathrm{II} \cdot{ }^{200}$ Thomas's apparently autonomous action was quickly confirmed by the subsequent declaration of support for Hawaiian independence by the British government. ${ }^{201}$

The Paulet episode was proof of the fragility of Hawaiian sovereignty and also of the dangers posed by foreigners' use of the Kingdom courts. When a young American lawyer named John Ricord arrived in the Kingdom in early 1844, he was quickly hired by Gerrit Judd to prevent his employment by parties hostile to the government. ${ }^{202}$ Ricord was given the task of constructing a western-style legal system backed up with enough authority that merchants would hesitate to question it. ${ }^{203} \mathrm{He}$ did this through single-handed importation of large chunks of common law and the ability to write dense opinions packed with citations. ${ }^{204}$

Simpson and the Mission for Hawaiian Independence 1840-1843, 20 HAWAIIAN J. HIST. 67, 7172 (1986).

198. Simpson's anti-Americanism was noticed by Thomas Farnham, the first American lawyer to visit the Hawaiian islands. Farnham sailed to Hawai' $i$ with Simpson in 1841. See THOMaS J. FarnHaM, TRAvels IN THE CaLIFORNIAS (New York, Saxton \& Miles 1846). Farnham wrote that Simpson, "like most British subjects abroad, [was] troubled with an irrepressible anxiety at the growing power of the States, and an overwhelming loyalty to the mother-country and its Sovereign skirts." Id. at 8.

199. Kuykendall points out that Paulet was not informed of the recent statement of the British government ensuring protection of Hawaiian sovereignty. See KUYKENDALL, supra note 5, at 212.

200. For descriptions of the entire Paulet episode, see BROOKES, supra note 81, at 124-38; and KUYKENDALL, supra note 5, at 206-26. Herman Melville was strongly supportive of the British takeover. See HERMAN MELVILLE, TYPEE: A PEEP AT POLYNESIAN LIFE 254-58 (Harrison Hayford et al. eds., Northwestern Univ. Press 1968) (1846).

201. See BROOKES, supra note 81 , at 136-38.

202. See KUYKENDALL, supra note 5, at 236. Judd explained his decision in a letter to R. Anderson: "The Government employs so many foreigners for the purpose of carrying out a simple system of uniform administration and a conduct towards foreigners which shall insure the regularity of proceedings and disarm all who would find fault with them as far as this is attainable." Letter from Gerrit Judd to R. Anderson (Dec. 16, 1846), in Family Records, House of Judd, Fragments II, Letters of Dr. Gerrit P. Judd, 1827-1872 (on file with the Hawaiian Mission Children's Society, Honolulu). For records of Ricord's decisions, see Archives of Hawai' $i$, Attorney General Complaints and Opinions, 1844 (vol. K).

203. See Silverman, supra note 14, at 56-58.

204. See id. at 57. Richard Armstrong, a member of the ABCFM mission, complained of Ricord's prose: "His style is excessively turgid, some sentences even bordering on bombastic; it is also very verbose, so much so that one gets lost amidst the underbrush of words thrown up in his way ...." Letter from Richard Armstrong to Gerrit Judd (Apr. 23, 1844) (on file with the Hawaiian Mission Children's Society, Honolulu). 
Unsurprisingly, few outside the government cared for Ricord. As the government newspaper noted later: "It was not to be expected that the introduction of a lawyer into a community where no lawyer had ever before been known, would not be disliked by many of the old residents." ${ }^{205}$ Reynolds complained in 1846 that Ricord busied himself "[d]rafting a Constitution, Laws, Lex Fori, \&c. None here believe he can be hired to go away." ${ }^{206}$ Ricord was also instrumental in establishing courts of chancery, admiralty, and probate. ${ }^{207}$ In doing so, he leaned heavily on the threat of renewed foreign hostility. For example, he informed the Hawaiian Legislature:

[The legislative duty of organizing proper civil and criminal tribunals] is of critical importance to His Majesty's Government; since most of the difficulties that have arisen between your country and other countries, have grown out of the trial of law suits and the enforcement of penalties. The provissional [sic] cession to Great Britain, sprung from the judicial administration of the laws in His Majesty's courts. ${ }^{208}$

To stop such difficulties from arising, henceforth, suits involving foreigners were to be heard in the Court of Oahu.

The judicial system became increasingly caucasianized in September 1845. Oahu Governor Kekuanao'a, who had previously heard suits by foreigners in Honolulu, appointed Lorrin Andrews, a missionary, to sit as his substitute in cases involving foreigners. ${ }^{209}$ Andrews set about drawing up rules for his court, including regulations for challenges to jury members, narrowing of pleadings, requirements of stamp and seal, and the necessary deposit for actions of replevin, among others. ${ }^{210}$

Ricord also contributed a series of organic acts, between 1845 and 1847, which served to westernize Hawaiian administration fully. The judiciary was organized by the third organic act, of September 1847, which was drafted by Ricord and William Little Lee, a Harvard-trained lawyer who had arrived in 1846 and was to become Hawai' $i$ 's first Chief Justice. ${ }^{211}$

205. THE POLYNESIAN (Honolulu), Apr. 12, 1845, at 192.

206. Letter from Stephen Reynolds to Thomas Larkin (Nov. 8, 1846), in 5 LARKIN PAPERS, supra note 156, at 269.

207. See KUYKENDALL, supra note 5, at 241-42.

208. JOHN RICORD, REPORT OF THE ATTORNEY GENERAL BY ORDER OF HIS MAJESTY, KING KAMEHAMEHA III READ BEFORE HIS MAJESTY, TO THE HAWAIIAN LEGISLATURE ON WEDNESDAY, MAY 21ST, 1845, at 17 (Honolulu, Polynesian Press 1845) (on file with the University of Hawai ' i-Manoa library).

209. See Frear, supra note 69, at 15.

210. See LORRIN ANDREWS, LEX ForI OF THE COURT OF OAHU OR RULES OF PRACTICE BEFORE HON. LORRIN ANDREWS (Honolulu, 1846).

211. For information on Lee, see S.C. DAMON, A TRIBUTE TO THE MEMORY OF HON. WILLIAM L. LEE, LATE ChIEF JUSTICE OF THE HAWAIIAN KINGDOM (Honolulu, H.M. Whitney's 
The organic act of 1847 created judicial districts and set up a superior court of law and equity. ${ }^{212}$ Under it, civil and criminal actions were distinguished, judicial independence was assured, and the discretionary power of judges was limited. ${ }^{213}$ One historian concludes that "[t]he organic acts had the effect of giving the country an administrative system and a judicial system of the Anglo-American type." 214

Various government statements from the mid-1840s reveal the importance of merchant needs in structuring the new courts. Ricord, the Attorney General, informed the Hawaiian Legislature that, among other things, the new courts needed to provide rules for agency, co-partnership, administration of estates, proper regulation of commercial paper, and the prevention of fraud in contractual relations. ${ }^{215}$ The editor of the government-run Polynesian reminded foreigners in 1845:

[I]t was the necessity of foreigners rather than natives, that required [the Court of Oahu], and consequently it has been created in great measure for their accommodation.... [1]t happened that mercantile and other dissensions arose among the foreigners, who, to settle their disputes appealed to the authorities of the country. To maintain the peace, and to give that protection to strangers which the comity of nations requires, the administration of justice in some form was indispensable. ${ }^{216}$

Judges in the new courts also referred to the mercantile ancestry of their jurisdiction. In analyzing the legislative history of the amendment to the original law on attachment, the court wrote: "The great mischief of this law was, that it placed the debtor's property and business in jeopardy, without giving him any security." 217

The first volume of Hawaiian Reports, which compiled cases heard between 1847 and 1856, also reflects the dominance of foreign commercial concerns in the newly-founded courts. Among the first issues the court dealt with were problems arising from the practice of attachment. ${ }^{218}$ Bankruptcy was also a common issue, as was the settlement of the estates of deceased

Press 1857); Silverman, supra note 14, at 58. For authorship of the organic acts, see KUYKENDALL, supra note 5, at 263 n.152. Lee's thoughts on his role in establishing the judiciary can be gauged from a number of letters written to his mentor, Simon Greenleaf, the Harvard professor and treatise writer. See Letters from William Little Lee to Simon Greenleaf (Nov. 2, 1847, Mar. 3, 1849, Aug. 16, 1849) (on file with the Bancroft Library, Univ. of Cal., Berkeley).

212. See KUYKENDALL, supra note 5, at 263.

213. See Frear, supra note 69 , at $16-22$.

214. KUYKENDALL, supra note 5, at 264.

215. See RICORD, supra note 208 , at 28-29.

216. THE POLYNESIAN (Honolulu), Apr. 5, 1845, at 188.

217. Shillaber v. Waldo, 1 Haw. 31,37 (1848).

218. See Wiley v. Nicholson, 1 Haw. 44 (1848); Waldo v. Pelly, 1 Haw. 53 (1848); Shillaber v. Waldo, 1 Haw. 31 (1848); Wiley v. Boyd, 1 Haw. 20 (1847). 
merchants. ${ }^{219}$ The role of the Hawaiian Supreme Court in creating land law, in the early years, by contrast, is much less significant. Only two cases from the first volume touch on the question of land titles, and, in both, the court defers to the Land Commission. ${ }^{220}$ The plaintiffs and defendants in the cases reported in this volume are overwhelmingly haole (Caucasian). ${ }^{221}$ The courts, in other words, were dominated by commercial disputes among foreigners. ${ }^{222}$

An oddly bifurcated court system resulted from these maneuvers. The judiciary administered law aimed at satisfying foreign needs, while recognizing its inappropriateness for the Hawaiian population. Chief Justice Lee confessed his frustration at balancing foreign and Hawaiian interests: "Both of these classes must live under the same laws, and how to strike out a proper medium equally adapted to the two, is what troubles me." ${ }^{223} \mathrm{He}$ noted: "Our commerce, which is quite extensive and for the most part in the hands of Foreigners, demands, and of course must have some laws in advance of the common mind." 224 Lee's frustration is indicative of the dilemmas of imposing a unitary, westernized legal system. Lee, like the monarch who hired him and the missionaries who supported him, was sympathetic to the needs of the Hawaiian people. Yet, he was constrained by the original purpose of his court-providing satisfactory justice for Honolulu's contentious merchants.

It would not be long, however, before the courts would expand outside the realm of intra-foreign disputes. With Lee's death in 1857, the sense of bifurcation he felt began to slip away from the Hawaiian courts. The crucial moment for newly-westernized courts came the following year when, in Oni v. Meek, ${ }^{225}$ the court assumed the power to define the customary rights belonging to the maka'ainana (commoners). In Oni, the court showed a new willingness to apply the rules of the western-oriented judiciary to the area of customary rights, a domain that had previously been guarded by the protections built in by the King and Legislature. Instead of the statutory

219. See Bullions v. Loring Bros. \& Co., 1 Haw. 372 (1856); Kinney v. Jones, 1 Haw. 419 (1856); Pelly v. Waldo, 1 Haw. 50 (1848). For cases involving merchant estates, see Clouston v. Ogden, 1 Haw. 309 (1855); In re Estate of Vida, 1 Haw. 152 (1853); and Nathan v. Estate of Vida, 1 Haw. 143 (1852).

220. See Kekiekie v. Dennis, 1 Haw. 69 (1851); Kukiiahu v. Gill, 1 Haw. 90 (1851).

221. This is partially a consequence of the fact that most of the cases reported were either from the Court of Oahu or the superior courts. Mari Matsuda found a willingness on the part of Hawaiians to bring cases to district courts. See Matsuda, supra note 16, at 24-26.

222. Evidence of this can be seen in the adoption of the law merchant into Hawaiian law. See Clouston v. Ogden, 1 Haw. 309, 313 (1855).

223. Letter from William Little Lee to Simon Greenleaf (Mar. 3, 1849), supra note 211.

224. Id.

225. 2 Haw. 87 (1858). 
assurances envisioned by the King, Oni left cultivators with only the scant protection of their private contractual relations. ${ }^{226}$

Oni has long been recognized as the moment when fee simple land tenure became the dominant system of land ownership in Hawai' $i$. Yet Oni also represents a less-noticed but equally epochal turning point in Hawaiian legal history: the end of a plural legal system. While Oni did not entirely eliminate other forms of dispute resolution-arbitration, for example, still occurred in the years after Oni was decided-it did alter the legal landscape drastically. Where different systems had previously existed independently of one another, now, for the first time, one of those systems claimed ultimate authority. Western law was established as the default regime. Any arrangements made in the expectation of enforcement in other courts, or according to other laws, could expect to be struck down if they did not meet common-law standards. Legal pluralism could only exist at the sufferance of the new, centralized, western legal system.

What did the Hawaiians think of this? The escalating control of Hawaiian government by foreigners did not go unnoticed. As early as 1845 , petitioners began to object to foreign encroachment. Thousands of Hawaiians from across the islands wrote Kamehameha III to protest the government's policies of hiring foreigners and allowing them to buy Hawaiian lands. ${ }^{227}$ As a group of petitioners in Maui warned: " $\left.\Pi\right] \mathrm{f}$ many foreigners are introduced into the kingdom at this time, this will be our end; we shall be the servants of the foreigners." ${ }^{228}$ Such fears, unfortunately, were both prescient and belated: prescient, in that they aptly predicted the course of Hawaiian history for the remainder of the century; and belated, since they arrived too late to effect any change. The die had been cast, and merchants, for reasons of their own, had been instrumental in the process.

\section{CONCLUSION}

One problem that emerges as we review the history of Hawai'i's westernized judiciary with an eye to modern relevance is the compatibility of a "recuperative" model and one based on recognition of legal pluralism. A "recuperative" model is, in many ways, an easier one from which to work. Old cases can be mined for new alternatives; old statutes can be reinterpreted in a more favorable light. Working within the system, the "recuperative" model allows for the development of ameliorative

226. See id. at 90 .

227. See KAME'ELEIHIWA, supra note 17, at 193-98; KuYKENDALL, supra note 5, at 257-60; SAHLINS, supra note 8, at 129-32; THE POLYNESIAN (Honolulu), Aug. 2, 1845, at 1; id. July 26, 1845 , at 40 . at 197.

228. THE FRIEND (Honolulu), Aug.1845, at 119, quoted in KAME'ELEIHIWA, supra note 17, 
strategies. Legal pluralism, by contrast, opens up a larger can of worms: Why should we embrace-even in a "recuperative" fashion-a legal system that we now view as a usurpation? Legal pluralism offers little in the way of immediately plausible alternatives. Returning to the records of merchant arbitrations will provide little guidance for resolving the practical questions surrounding Native Hawaiian rights today.

Recognition of this new genealogy of the westernized courts, however, should not cause critical historicists and others interested in the preservation and expansion of Native Hawaiian rights to abandon their "recuperative" project. Recognizing the plural legal heritage of the Hawaiian Kingdom should allow critics to press further in their questioning of the continued relevance of Kingdom precedents. It provides a broader foundation for skepticism toward the continuing attempts to balance respect for precedent with concessions to Native Hawaiian rights. Kalipi, for example, questions the scope of rights covered by the decision in Oni v. Meek, but it allows the decision itself to stand. ${ }^{229}$

We need to ask ourselves why the decisions of a foreign-oriented court should be used today to determine the scope of Native Hawaiian rights. While it may be appealing to see the adoption of a western-style legal system as an act of resistance to colonization, ${ }^{230}$ it is important to realize that it was the establishment itself-not the behavior of the courts so established-that was resistant. Within the courts, the law applied was strictly western. The courts themselves could not stave off the demands of the resident foreign community for application of western-style judgments according to western law. Unlike the bargain that established a western system of land tenure, whereby the King relinquished some of his rights in order to ensure the preservation of maka'ainana rights, no assurances were received by the King in his creation of western judiciary.

Moreover, unlike the individual components of the plural legal system that preceded it, the new legal system relentlessly insisted that there was no corner of Hawaiian life into which its authority did not extend. It was impossible to prevent the encroachment of the westernized judiciary into new realms, including land tenure, given the conviction among foreigners that land rights, too, were properly adjudicated according to western law. In Oni v. Meek the westernized court put an end to a system of legal pluralism that recognized the existence of multiple bodies of law. It is this step, taken ten years after the beginning of judical westernization, that is obscured by the conventional genealogy that identifies westernization from the very outset with land hunger. Uncovering the background leading up to this step reminds us that even mountains have antecedents.

229. See supra note 40 .

230. See supra text accompanying note 125 . 